\title{
Effects of gamma irradiation and periodate oxidation on the structure of dextrin assessed by mass spectrometry
} \author{
M. Rosário M. Domingues ${ }^{\mathrm{b}}$, Miguel Gama ${ }^{\mathrm{a}}$ \\ ${ }^{\text {a }}$ CEB - Centre of Biological Engineering, University of Minho, Campus de Gualtar, 4710-057 Braga, Portugal \\ ${ }^{\mathrm{b}}$ QOPNA, Department of Chemistry, University of Aveiro, Campus de Santiago, 3810-193 Aveiro, Portugal \\ c CICECO, Department of Chemistry, University of Aveiro, Campus de Santiago, 3810-193 Aveiro, Portugal \\ d IONISOS, Parc Dombes Côtière Activités, Route de Balan, F-01120 Dagneux, France
}

Isabel Pereira $^{\mathrm{a}, *}$, Joana Simões ${ }^{\mathrm{b}}$, Dmitry V. Evtyugin ${ }^{\mathrm{c}}$, Sophie Rouif ${ }^{\mathrm{d}}$, Manuel A. Coimbra ${ }^{\mathrm{b}}$,

\section{A R T I C L E I N F O}

\section{Keywords:}

Dextrin

Periodate oxidation

Gamma irradiation

Electrospray ionization mass spectrometry

MALDI-MS

Biomedical application

\begin{abstract}
A B S T R A C T
Sterilization of biomaterials by gamma irradiation should not change its structure, since this may affect also its bioactivity. In this work, dextrin and periodate-oxidized dextrin (ODEX), both irradiated and non-irradiated, were hydrolysed by $\alpha$-amylase and the obtained oligosaccharides were fractionated by ligand-exchange/size exclusion chromatography and analyzed by matrix-assisted laser desorption/ionization (MALDI-MS) and electrospray ionization (ESI-MS ${ }^{n}$ ) mass spectrometry. This allowed the identification of structures formed during partial periodate oxidation, which displayed aldehyde groups in different positions of dextrin backbone, according to the type of residue which was oxidized. Importantly, gamma irradiation did not structurally change either dextrin or ODEX, showing that it can be used as suitable terminal sterilization method of these materials for biomedical applications. To our best knowledge, this is the first report using MS-based techniques to evaluate the effects of partial periodate oxidation and of gamma irradiation on polysaccharides and, in particular, on dextrin and its oxidized form.
\end{abstract}

\section{Introduction}

Dextrins are low-molecular-weight carbohydrates produced by partial hydrolysis of glycogen or starch obtained under acidic and/or enzymatic conditions [1]. They are composed by a linear $(\alpha 1 \rightarrow 4)$-Dglucose residues backbone, branched with $(\alpha 1 \rightarrow 4,6)$-linked-D-glucose residues containing terminal or $(\alpha 1 \rightarrow 4)$-D-glucose oligomers. Some dextrins also present $(\alpha 1 \rightarrow 6)$-D-glucose residues in small percentage $[2,3]$.

Dextrin is a low cost, broadly available raw material widely used in many industrial applications, such as adhesives in the manufacture of gummed tapes, textiles and paper, as moisturiser in cosmetics and accepted in food applications as a generally-recognized-as-safe (GRAS) ingredient $[1,3]$. Regarding biomedical applications, dextrin is still relatively unexplored, being clinically used as a peritoneal dialysis solution that can also perform as a drug delivery solution [4-6], and as wound dressing agent [7]. During last decade, due to its properties, which include the solubility in both water and DMSO, availability in medical grade, and availability of hydroxyl groups, dextrin has been explored for the design and fabrication of (nano)hydrogels suitable for controlled release applications, tissue engineering scaffolds, excipient in tablets, bioadhesives or drug conjugates. Such applications have been extensively reviewed by Gonçalves et al. [1] and by Das and Pal [8].

Dextrin was used by our research group to develop a fully resorbable and injectable hydrogel. Dextrin was firstly oxidized (ODEX) with sodium periodate $\left(\mathrm{NaIO}_{4}\right)$ and then cross-linked with adipic acid dihydrazide, a non-toxic cross-linking molecule. The cross-linked ODEX is an in situ gelling hydrogel, able to incorporate nanogels, cells, biomolecules, and granular ceramics for bone regeneration applications $[2,9,10]$.

Periodate oxidation ("glycol cleavage" oxidation) is a simple and effective method for introduction reactive groups in polysaccharide backbones. It is a catalysis-free aqueous reaction, where periodate ion $\left(\mathrm{IO}_{4}{ }^{-}\right)$attacks vicinal diols to cleave the carbon-carbon bond, leading to the formation of two aldehyde groups [11]. Initially, this method was routinely used in the characterization and elucidation of the polysaccharide structure through complete oxidation [11]. In later years, low and mild periodate oxidations have been used to functionalize

\footnotetext{
* Corresponding author.

E-mail addresses: isabelsofia.isport@gmail.com (I. Pereira), joana.simoes@ua.pt (J. Simões), dmitrye@ua.pt (D.V. Evtyugin), sophie.rouif@ionisos.fr (S. Rouif), mac@ua.pt (M.A. Coimbra), mrd@ua.pt (M.R.M. Domingues), fmgama@deb.uminho.pt (M. Gama).
} 
polysaccharides: the aldehyde groups along the backbone serve as reactive chemical anchors for further reactions with nucleophilic molecules, allowing the immobilization/stabilization of drugs/biomolecules [12-14] and the formation of hydrogels $[9,15,16]$.

Partial periodate oxidation has been extensively investigated in many polysaccharides, such as cellulose $[17,18]$, alginate $[16,19,20]$, hyaluronate [21], starch [22,23], pectin [24], chitosan [25], and dextran $[15,26,27]$. Such works have been mainly focused on the characterization of physico-chemical properties of the oxidized derivatives, such as molecular weight $(M w)$, radius of gyration $\left(R_{G}\right)$, persistence length, intrinsic viscosity, rheology, thermal properties, crystallinity, and reaction kinetics. Fourier transform infrared (FTIR) spectroscopy, ${ }^{1} \mathrm{H}$ and/or ${ }^{13} \mathrm{C}$ nuclear magnetic resonance (NMR) and colorimetric titrations have been used to detect and/or quantify the aldehydes produced, which form hydrated, hemiacetals or hemialdal structures $[11,15,27]$, allowing to determine the oxidation degree of the polysaccharides. However, published data still lacks comprehensive characterization on the polysaccharides structural modifications during partial periodate oxidation.

Sterilization is a fundamental step for the manufacturing of biomaterials and implantable medical devices. However, many sterilization procedures have been shown to deeply affect polymer properties. Ionizing sterilization is the most popular procedure for medical devices sterilization [28-31]. No chemicals are needed, there is no additional processing and there is no waste. The main sources of radiation used in sterilization process are electron beam (e-beam) generated from electron accelerators, and gamma irradiation from radioactive sources, mainly ${ }^{60} \mathrm{Co}$ [30]. Gamma irradiation has been the most used sterilization technique, while e-beam is a newer and promising process for the sterilization of medical devices. Gamma irradiation has the advantages to display a higher penetration ability, inducing homogeneous dose delivery in thick products or large batches [30-32]. Nevertheless, ionizing irradiation may produce free radicals, resulting from the radiolysis of water molecules, which can react with the polysaccharide sugar residues and modify its chemical structure and molecular weight $[31,33,34]$. In this context, it is relevant performing detailed studies on chemical structure of the oxidized dextrin after irradiation.

The main goal of this work was to evaluate the effect of partial periodate oxidation followed by gamma irradiation on dextrin chemical structure for biomedical applications. The sugars and glycosidic-linkage composition were analysed before and after oxidation and irradiation. Mass spectrometry (MS), namely matrix-assisted laser desorption/ionization mass spectrometry (MALDI-MS), electrospray ionization mass spectrometry (ESI-MS) and tandem mass spectrometry (ESI-MS/MS) was used to identify and characterize the structural modifications induced by oxidation and irradiation processes. For this, the samples were hydrolysed with $\alpha$-amylase and further fractionated by semi-preparative ligand-exchange/size exclusion chromatography (LEX/SEC). MS has been used for the structural characterization of polysaccharides and oligosaccharides [35-37], including the oxidation of oligosaccharides [38-40]. Biomolecules, and namely polysaccharides (cellulose, dextran, dextrin, etc), are being increasingly used in the field of biomedicine. Thus, the assessment of the effects of irradiation, commonly used to sterilize biomaterials, must be comprehensively carried out, in order to understand whether significant changes occur, potentially compromising functionality/bioactivity.

\section{Material and methods}

\subsection{Materials}

All reagents used were of laboratory grade from Sigma-Aldrich, unless stated otherwise. Dextrin was from Tackidex B 167 (Batch E 1445), generously provided by Roquette (Lestrem, France). Its structural characterization was done in a previous study [2].

\subsection{Dextrin oxidation}

Dextrin oxidation was performed as described by Molinos et al. [9], with some modifications. Briefly, aqueous solutions of dextrin (14 g; $2 \%$ $\mathrm{w} / \mathrm{v}$ ) were oxidized in the dark with $7.39 \mathrm{~g}$ of sodium $\mathrm{m}$-periodate, to yield a theoretical degree of oxidation of $40 \%$, at room temperature and with stirring. After $20 \mathrm{~h}$, the oxidation reaction was stopped by adding drop wise $3.32 \mathrm{~mL}$ of diethylene glycol under stirring for $0.5 \mathrm{~h}$ to reduce any unreacted periodate. Sodium $m$-periodate and diethylene glycol were removed by ultrafiltration, using a membrane with a molecular weight cut-off of $1000 \mathrm{Da}$ (Merk Millipore, Billerica, MA, USA), and then the oxidized dextrin (ODEX) was lyophilized. The yield was about $69.5 \% \pm 3.3$ of ODEX in each batch ( $n=12$ batches).

\subsection{Determination of bioburden and sterilization dose}

The initial bioburden (initial microbiological contamination) of non-sterilized ODEX was determined using conventional microbiological techniques and according to ISO 11737-1 guidelines [41]. Briefly, ODEX solutions using sterile phosphate buffered saline solution (PBS) with $\mathrm{pH} 7.4$ were prepared at concentration $30 \% \mathrm{w} / \mathrm{v}$, and allowed to stir for complete dissolution of ODEX and microorganisms' extraction (seven batches were used). Then, ODEX solution was plated on tryptic soy (TSA) medium (3 plates/batch) for growing of fastidious microorganisms and incubated at $30^{\circ} \mathrm{C}$. After 7 days, colony-forming units (CFU) were counted and the average bioburden determined. The obtained value was used to determine the irradiation dose necessary to obtain a sterility assurance level (SAL) of at least $10^{-6}$, using for that the tabulated values depicted in ISO 11137-2 [42].

\subsection{Gamma irradiation}

Gamma irradiation was performed by IONISOS (Dagneux, France). Dextrin and ODEX were dissolved 30\% w/v in PBS with pH 7.4 and irradiated using a ${ }^{60} \mathrm{Co}$ source, at $20 \mathrm{kGy}$ (average dose rate of $2 \mathrm{kGy} /$ $\mathrm{h}$ ), at room temperature. The dextrin was also irradiated at $10 \mathrm{kGy}(2$ $\mathrm{kGy} / \mathrm{h}$ ) for comparison of the irradiation effects on the polysaccharidés structure.

\subsection{Sterility test}

The efficacy of gamma irradiation sterilization for ODEX samples was evaluated by a sterility test based on conventional microbiological techniques and described in ISO 11737-2 [43] with slight modifications. Briefly, after the sterilization processes, samples were transferred to test tubes containing tryptic soy broth (TSB) medium for growing of fastidious microorganisms and incubated under agitation, at $30{ }^{\circ} \mathrm{C}$ for 3 weeks. Culture medium alone served as negative control, whereas non-irradiated ODEX served as positive control. The turbidity of the broth indicated contamination and inefficient sterilization, while a clear, uncontaminated broth indicated efficient sterilization, producing a sterile solution. Sterility tests were carried out in triplicate.

\subsection{Sugars and linkage analyses}

Neutral sugars were determined by gas chromatography (GC) as alditol acetates [44]. The pre-hydrolysis was performed with $\mathrm{H}_{2} \mathrm{SO}_{4}$ $72 \%$ at room temperature for $3 \mathrm{~h}$ followed by hydrolysis for $1 \mathrm{~h}$ in $\mathrm{H}_{2} \mathrm{SO}_{4} 2 \mathrm{M}$ at $120^{\circ} \mathrm{C}$. Monosaccharides were reduced with $\mathrm{NaBH}_{4}(15 \%$ in $\mathrm{NH}_{3} 3 \mathrm{M}$ ) for $1 \mathrm{~h}$ at $30^{\circ} \mathrm{C}$ and subsequently acetylated with acetic anhydride $(3 \mathrm{~mL})$ in the presence of 1 -methylimidazole $(450 \mu \mathrm{L})$ for $30 \mathrm{~min}$ at $30^{\circ} \mathrm{C}$. Alditol acetate derivatives were separated with dichloromethane and analysed by GC with a FID detector and equipped with a $30 \mathrm{~m}$ column DB-225 (J\&W Scientific, Folsom, CA, USA) with i.d. and film thickness of $0.25 \mathrm{~mm}$ and $0.15 \mu \mathrm{m}$, respectively. The following oven temperature program used: the initial temperature was set at 
$200^{\circ} \mathrm{C}$ and increased at a rate of $40^{\circ} \mathrm{C} / \mathrm{min}$ until $220^{\circ} \mathrm{C}$; then it was kept constant for $7 \mathrm{~min}$ and again increased at a rate of $20^{\circ} \mathrm{C} / \mathrm{min}$ until $230^{\circ} \mathrm{C}$; then, the temperature was kept constant for $1 \mathrm{~min}$. The injector and detector temperatures were, respectively, 220 and $230^{\circ} \mathrm{C}$. The flow rate of the carrier gas $\left(\mathrm{H}_{2}\right)$ was set at $1.7 \mathrm{~mL} / \mathrm{min}$.

Uronic acids were determined colorimetrically according to a modification [44] of the method of Blumenkrantz and Asboe-Hansen [45]. Samples were prepared by pre-hydrolysis in $0.2 \mathrm{~mL}$ of $72 \% \mathrm{H}_{2} \mathrm{SO}_{4}$ for $3 \mathrm{~h}$ at room temperature followed by hydrolysis for $1 \mathrm{~h}$ in $\mathrm{H}_{2} \mathrm{SO}_{4} 1 \mathrm{M}$ at $100{ }^{\circ} \mathrm{C}$. A calibration curve was made with D-galacturonic acid.

Linkage analysis was carried out by methylation as described by Ciucanu and Kerek [46] with modifications. Dextrin samples (1-2 mg) were dissolved in $1 \mathrm{~mL}$ of anhydrous dimethylsulfoxide (DMSO). Sodium hydroxide $(\mathrm{NaOH})$ pellets were ground with a pestle in a dry mortar to get a fine powder in a $\mathrm{N}_{2}$ atmosphere; then, powdered $\mathrm{NaOH}$ (about $40 \mathrm{mg}$ ) was added and the samples were methylated with $\mathrm{CH}_{3} \mathrm{I}$ $(80 \mu \mathrm{L})$ during $20 \mathrm{~min}$. The samples were dissolved in $3 \mathrm{~mL}$ of chloroform:methanol $(1: 1, \mathrm{v} / \mathrm{v})$ and dialyzed against water:ethanol $(1: 1, \mathrm{v} /$ v) using a membrane with a molecular weight cut-off of $1000 \mathrm{Da}$. The methylated fractions were also carboxyl-reduced by a modification of the method described by Nunes et al. [37]. The partially methylated alditol acetates (PMAA) were separated and analyzed by gas chromatography with mass spectrometry detector (GC-MS) on a Shimadzu GCMS-QP2010 Plus (Kyoto, Japan). The GC was equipped with a DB-1 (J\& W Scientific, Folsom, CA, USA) capillary column (30 m length, $0.25 \mathrm{~mm}$ of internal diameter and $0.15 \mathrm{~m}$ of film thickness). The samples were injected in split less mode (time of split less $5 \mathrm{~min}$ ), with the injector operating at $220^{\circ} \mathrm{C}$, and using the following temperature program: $45^{\circ} \mathrm{C}$ for $5 \mathrm{~min}$ with a linear increase of $10^{\circ} \mathrm{C} / \mathrm{min}$ up to $140^{\circ} \mathrm{C}$, and standing for $5 \mathrm{~min}$ at this temperature, followed by linear increase of $0.5^{\circ} \mathrm{C} / \mathrm{min}$ up to $170^{\circ} \mathrm{C}$, and standing for $1 \mathrm{~min}$ at this temperature, followed by linear increase of $15^{\circ} \mathrm{C} / \mathrm{min}$ up to $280^{\circ} \mathrm{C}$, with further $5 \mathrm{~min}$ at $280^{\circ} \mathrm{C}$. The carrier gas was helium with a flow rate of $1.7 \mathrm{~mL} /$ min and a column head pressure of 2.8 psi. The GC was connected to an Agilent 5973 mass quadrupole selective detector operating with an electron impact mode at $70 \mathrm{eV}$ and scanning the range $m / z 40-500$ in a 1 s cycle in a full scan mode acquisition.

\subsection{Size exclusion chromatography analysis}

About 4-5 mg of ODEX was dissolved in $500 \mu \mathrm{L}$ of $0.1 \mathrm{M} \mathrm{NaNO}_{3}$ aqueous solution at room temperature, during $180 \mathrm{~min}$ reaching a sample concentration of ca. $1 \%$. The size exclusion chromatography (SEC) analysis was carried out using two PL aquagel-OH MIXED $8 \mu \mathrm{m}$ $300 \times 7.5 \mathrm{~mm}$ columns protected by a PL aquagel-OH Guard $8 \mu \mathrm{m}$ precolumn on a PL-GPC 110 system (Polymer Laboratories, UK). The columns, injector system, and the detector (RI) were maintained at $36^{\circ} \mathrm{C}$ during the analysis. The eluent $\left(0.1 \mathrm{M} \mathrm{NaNO}_{3}\right)$ was pumped at a flow rate of $0.9 \mathrm{~mL} / \mathrm{min}$. The injected volume was $100 \mu \mathrm{L}$. The columns were calibrated with pullulans (Polymer Laboratories, UK) in the range $0.7-48.0 \mathrm{kDa}$, allowing the determination of an estimated value of molecular weight $(M w)$, designated as apparent $M w$.

\subsection{Enzymatic hydrolysis and chromatographic separation}

Dextrin and ODEX (2-3 mg) were hydrolyzed with an $\alpha$-amylase (EC 3.2.1.1) from Bacillus subtilis (Fluka, $625 \mathrm{U} / \mathrm{mg}$ ) in $1 \mathrm{~mL}$ ammonium hydrogen carbonate $(5 \mathrm{mM}, \mathrm{pH} 7.0)$. The enzymatic hydrolysis was performed during $24 \mathrm{~h}$, at $37^{\circ} \mathrm{C}$ with continuous stirring.

The resulting oligosaccharides were separated by semi-preparative LEX/SEC on a high-performance liquid chromatograph equipped with a Shodex sugar KS 2002 column (300 mm of length and $20 \mathrm{~mm}$ of internal diameter) from Showa Denko K. K. (Tokyo, Japan). The column was maintained at $30^{\circ} \mathrm{C}$, the injected sample volume was $500 \mu \mathrm{L}$ and ultrapure water was used as eluent at a flow rate of $2.80 \mathrm{~mL} / \mathrm{min}$. A refractive index detector (Knauer K-2401, Berlin, Germany) was used. All collected fractions were dried, then neutral fractions were redissolved in $100 \mu \mathrm{L}$ of ultrapure water, while acidic fractions were redissolved in $50 \mu \mathrm{L}$ and kept frozen at $-20^{\circ} \mathrm{C}$ until analysis by MS. Before MS analysis, acidic fractions were decationized being incubated with AG $50 \mathrm{~W}$-X8 cation exchange resin (Bio-Rad Laboratories, Hercules, CA) for $15 \mathrm{~min}$ at room temperature.

\subsection{Matrix-Assisted Laser Desorption/Ionization Mass Spectrometry (MALDI-MS)}

Samples preparation for MALDI analysis was performed by mixing 4 $\mu \mathrm{L}$ of each sample, previously dissolved in water, to $4 \mu \mathrm{L}$ of 2,5-dihydroxybenzoic acid matrix $(10 \mathrm{mg} / \mathrm{mL}$ in methanol). From this mixture, $0.5 \mu \mathrm{L}$ were deposited on the MALDI plate, allowed to dry at ambient conditions. MALDI-MS spectra were acquired using a MALDI-TOF/TOF Applied Biosystems 4800 Proteomics Analyzer (Applied Biosystems, Framingham, MA) instrument equipped with a nitrogen laser emitting at $337 \mathrm{~nm}$ and operating in a reflectron mode. Full-scan mass spectra ranging from $\mathrm{m} / \mathrm{z} 500$ to 4000 were acquired in the positive mode.

\subsection{Electrospray ionization mass spectrometry (ESI-MS) and tandem mass spectrometry (ESI-MS/MS)}

The ESI-MS and ESI-MS/MS experiments were carried out in the positive mode in a LXQ linear ion trap (LIT) mass spectrometer (ThermoFinningan, San Jose, CA). Samples were diluted in methanol/ water (1:1) containing formic acid $0.1 \%(\mathrm{v} / \mathrm{v})$ and introduced into the electrospray source at a flow rate of $8 \mu \mathrm{L} / \mathrm{min}$. The ESI conditions were as follows: nitrogen sheath gas $30 \mathrm{psi}$, spray voltage $5 \mathrm{kV}$, capillary temperature, $275^{\circ} \mathrm{C}$, capillary voltage $1 \mathrm{~V}$, and the tube lens voltage, $40 \mathrm{~V}$. Nitrogen was used as nebulizing and drying gas. ESI-MS spectra were acquired scanning the mass range from $\mathrm{m} / \mathrm{z} 100$ to 1500 . In the MS/MS experiments, the collision energy used was set between 15 and 40 of normalized values. The data were processed using an Xcalibur data system (version 2.0).

\section{Results and discussion}

\subsection{Determination of bioburden and sterility verification}

The average bioburden (microbiological contamination) of ODEX before sterilization was $10.3 \pm 7.5 \mathrm{CFU} / \mathrm{g}$. A gamma irradiation dose of $20 \mathrm{kGy}$ ensures the achievement of a SAL of at least $10^{-6}$ of the product. To confirm that such dose was enough, a sterility test after ODEX irradiation was performed. After 3 weeks of incubation in TSB, the samples were visually checked for turbidity. Sterile TSB, and irradiated ODEX were clear. At the same time, contamination evidenced by a cloudy aspect, was observed for the non-irradiated ODEX samples. Hence the results suggested that gamma irradiation at $20 \mathrm{kGy}(2 \mathrm{kGy} / \mathrm{h})$ effectively sterilizes ODEX solutions. The investigation of the eventual post-sterilization changes in the structure of polymers becomes fundamental, since such alterations can compromise their functionality/ bioactivity.

\subsection{Structural analysis of dextrin and ODEX}

The dextrin used in this work, Tackidex, is a medical grade dextrin obtained by thermal and acidic hydrolysis of potato starch. A structural characterization of this material has been performed in a previously study [2], that is now extended to the oxidized and irradiated dextrin. Sugar analyses revealed that all samples of dextrin and ODEX are composed only by glucose, as confirmed by glycosidic-linkage analysis (Table 1). The oxidation process reduced the glucose amount by $44.4 \%$ (Table 1), while gamma irradiation of ODEX did not change its amount of glucose.

In the dextrin samples, glucose occurs mainly as $(1 \rightarrow 4)$-linked 
Table 1

Glycosidic-linkage analysis of irradiated (10 and $20 \mathrm{kGy}$ ) and non-irradiated (mol \%) dextrin and oxidized dextrin (ODEX).

\begin{tabular}{|c|c|c|c|c|c|}
\hline \multirow[b]{2}{*}{ Linkages } & \multicolumn{3}{|c|}{ Dextrin } & \multicolumn{2}{|l|}{ ODEX } \\
\hline & $0 \mathrm{kGy}$ & $10 \mathrm{kGy}$ & 20 kGy & $0 \mathrm{kGy}$ & $20 \mathrm{kGy}$ \\
\hline T-Glcp & 15.8 & 16.6 & 16.4 & 28.1 & 27.0 \\
\hline 4-Glcp & 77.0 & 77.3 & 76.3 & 62.2 & 62.5 \\
\hline 6-Glcp & 3.2 & 3.2 & 3.3 & 4.8 & 4.7 \\
\hline 4,6-Glcp & 4.0 & 2.8 & 4.1 & 5.3 & 5.8 \\
\hline Glucose loss \% & - & - & - & 44.4 & 44.5 \\
\hline
\end{tabular}

residues with small amounts of $(1 \rightarrow 4,6)$ - and $(1 \rightarrow 6)$-linked residues (Table 1), as observed previously [2]. Similar results were obtained for the ODEX samples, with a slightly higher relative amount of branched, 6-Glcp and terminally linked residues, corresponding to a lower relative amount of 4-Glcp. Nevertheless, a high loss of glucose occurred in the oxidation process, as could be expected (Table 1). Shorter and oxidized residues likely formed during the oxidation reactions, such as glyoxal and D-erythrose [47], was not detected by methylation analysis due to the higher volatility of their alditol acetates. The linkage analysis showed that gamma irradiation and oxidation processes did not induce the formation of new glycosidic bonds. The formation of new glycosidic bonds during oxidation process was not expected, since periodate ion is a highly selective glycol-cleaving oxidant [11]. However, it is known that the aldehyde groups formed during oxidation react with nearby hydroxyl groups, forming hemiacetals or hemialdals, in water. These transitory events could be either intra or inter-residue and, in certain situations, may interfere with the oxidation evolution, the polysaccharide stability/degradability, and with the determination of oxidation degree $[11,27,48,49]$. Irradiation seems not to change substantially the relative frequencies of the different linkages. It is known that gamma irradiation generates free radicals, in a dose dependent manner, which are capable of cleaving glycosidic bonds, leading to depolymerization of the polysaccharides, including starch and its derivatives [50-54]. The depolymerization reaction is dependent of many factors, such as atmosphere (e.g. presence or absence of $\mathrm{O}_{2}$ ), temperature/phase and dose rate used during irradiation process [30,34]. Generally, higher irradiation dose levels and/or higher dose rates promote greater depolymerization [50-52,55-59]. The origin and type of polysaccharide are also relevant. For instance, it has been reported that alginates depolymerize even under lower doses of gamma irradiation (0.5-10 kGy) [60-63]. It is possible that the presence of carboxyl groups in alginate residues increases the production of radical species, leading to further depolymerization [64]. Moreover it has been demonstrated that guluronic acid/mannuronic acid ratio is an important factor for controlling the degradation rate of sodium alginate $[62,63]$. Concerning to dextrin, only one report was found [52]. In that work, dextrin $(0.8-70 \mathrm{kDa})$ in solid state was irradiated at dose range between 5 and $100 \mathrm{kGy}$, at higher dose rate $(6.316 \mathrm{kGy} / \mathrm{h})$, and a reduction of dextrin viscosity was observed already for $5 \mathrm{kGy}$. In this work, a very small degradation was detected in dextrin solutions irradiated $20 \mathrm{kGy}$ : according to linkage analysis, dextrin displayed an increase of terminally-linked Glc residues of only $0.6 \%$ (mol) (Table 1 ). The concentration of the solutions was $30 \%(\mathrm{w} / \mathrm{v})$, while most works use dilute solutions (below 10\%) to study the effect of gamma irradiation [30,65]. It has been reported that degradation decreases with increasing polysaccharide concentration (1-4\% w/v) [57-59]. Additionally, SEC analysis were performed to confirm whether gamma irradiation affect the oxidized dextrin. The results (Table 2) revealed that the apparent $M w$ of ODEX before $(3610 \mathrm{Da})$ and after (3790 Da) gamma irradiation were very similar, as well as the polydispersity $(M w / M n)-2.11$ for ODEX non-irradiated and 2.23 for ODEX irradiated at $20 \mathrm{kGy}$. The SEC results, together with the linkages analysis, suggest that gamma irradiation did not alter the length of ODEX chains or its hydrodynamic volume. It may
Table 2

Results on SEC analysis of ODEX samples before and after the gamma irradiation.

\begin{tabular}{lccc}
\hline Sample & $M w$, Da & $M n$, Da & $M w / M n$ \\
\hline ODEX & 3610 & 1705 & 2.11 \\
ODEX 20 kGy & 3790 & 1700 & 2.23 \\
\hline
\end{tabular}

be hypothesized that the low $M w$ of the dextrin used in this work (4.5 $\mathrm{kDa}$ ) [2] makes it difficult the detection of depolymerization. Further studies should be performed, e.g. using MALLS or viscosity analysis, to evaluate the effect of the concentration of dextrin, as well as the impact of $M w$ on the depolymerisation reaction. Nevertheless, the evidences obtained point towards a very low depolymerisation under the conditions used in this work.

To our best knowledge, this is the first report that study the effect gamma irradiation on low molecular polysaccharides containing dialdehydes groups. The obtained results show that gamma irradiation can be used as a terminal sterilization process of dextrin and aldehydemodified dextrin for biomedical applications, since it does not induce major structural modifications. Although gamma irradiation has been the most used sterilizing technique, e-beam irradiation is attracting more attention recently for the sterilization of polymeric-based medical devices [31]. Generally, e-beam irradiation causes less radiolysis than gamma irradiation, and less polymer degradation is the result of shorter processing times with higher irradiation dose rates. While gamma irradiation delivers a certain dose over a period of minutes to hours to a large volume of product, e-beam irradiation delivers the same dose in a few seconds but to a very small volume. Generally, similar radicals are formed when irradiating the materials by gamma irradiation and ebeam [32]. Therefore, it can be hypothesized that applying the same dose (20 kGy) of e-beam irradiation, no major structural modifications should occur. However, further studies should be performed to confirm this assumption.

\subsection{Fractionation of oligosaccharides and modified oligosaccharides obtained by partial enzymatic hydrolysis using LEX/SEC chromatography}

Dextrin and ODEX samples were selectively hydrolyzed by $\alpha$-amylase, an endoglucanase which cleaves $(\alpha 1 \rightarrow 4)$-D-glucose linkages. This selective hydrolysis yields oligosaccharides of low molecular weight, allowing their separation by LEX/SEC and simplifying further MS spectra analyses. LEX/SEC provides an effective separation of acidic and neutral products, as well as the fractionation of neutral oligosaccharides according to their size $[39,40,66]$.

The LEX/SEC chromatograms of dextrin and ODEX (irradiated and non-irradiated samples) are shown in Fig. 1. According to previous studies [38-40], the peak with the lowest elution time (10 min) was assigned to oligosaccharides bearing acidic residues, the one at $12 \mathrm{~min}$ was attributed to the enzyme, and the other peaks at 13-20 min were assigned to the neutral oligosaccharides.

The fractions eluted at $10 \mathrm{~min}$ (F10), $14 \mathrm{~min}$ (F14), $17 \mathrm{~min}$ (F17) and 19 min (F19) were selected to be analyzed by MALDI-MS, ESI-MS, and ESI-MS/MS. MS analyses allowed to assign F14, present in all samples, mainly to oligosaccharides with higher molecular weight, containing 4 to 9 residues, modified or not. The F17 observed only in dextrin samples (Fig. 1A-C), was assigned to oligosaccharides containing 2 and 5 residues. F19 corresponded mainly to mono-, di- and trisaccharides, also with or without modifications. The di- and trisaccharides thus eluted in fractions F17 and F19. In ODEX samples (Fig. 1D and E), the peak corresponding to F19 decreased significantly in relation to the other ones, probably due to the loss of glucose during the oxidation process. These results allowed to confirm that sodium periodate oxidation promoted structural modifications to dextrin. Comparing the chromatograms of the irradiated and non-irradiated 


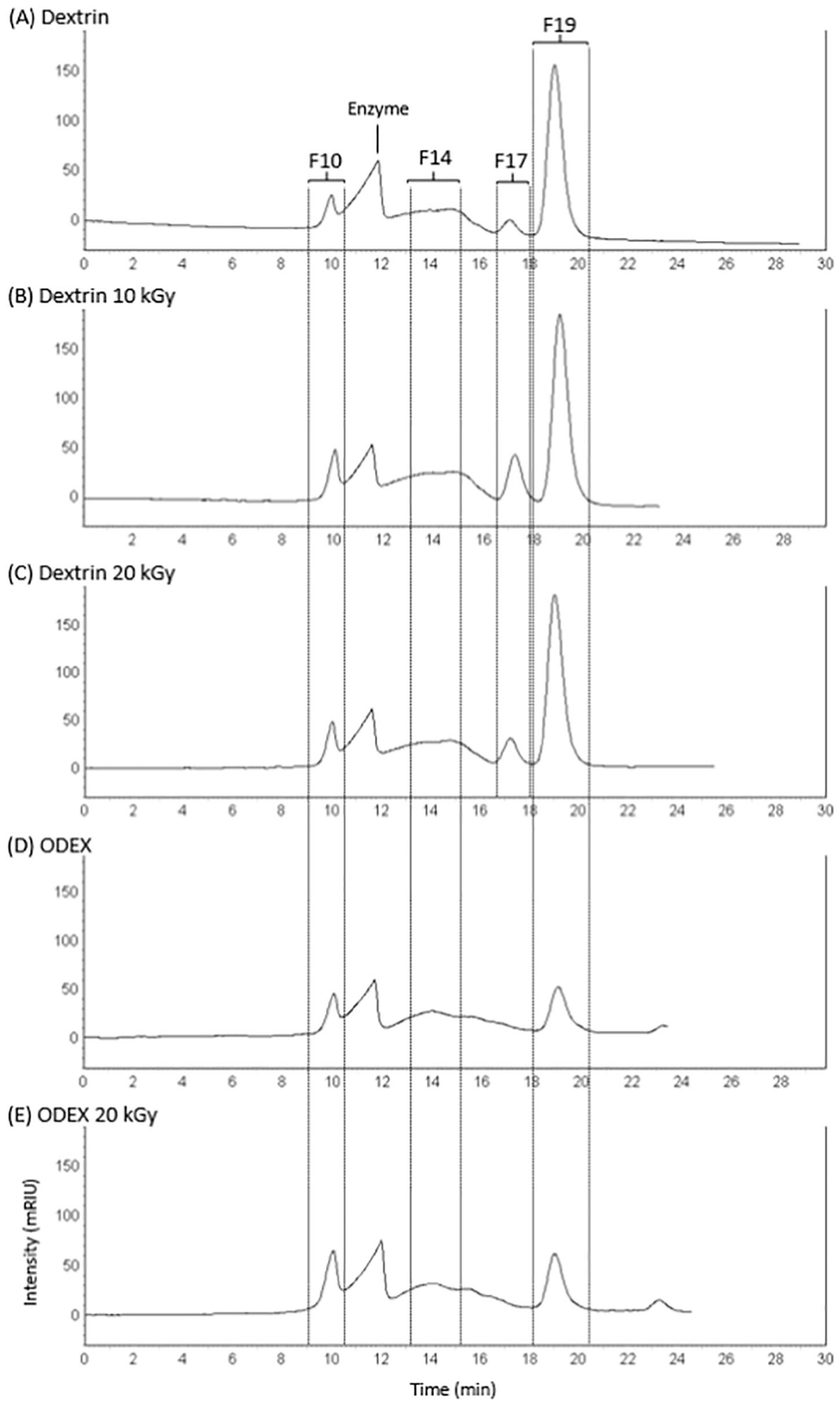

Fig. 1. LEX/SEC chromatograms of the oligosaccharides obtained after partial enzymatic hydrolysis with $\alpha$-amylose of the dextrin non-irradiated (A), irradiated at $10 \mathrm{kGy}$ (B) and at $20 \mathrm{kGy}$ (C), and of the ODEX non-irradiated (D) and irradiated at $20 \mathrm{kGy}$ (E).

samples, the LEX/SEC profile was similar, thus suggesting that gamma irradiation did not affect the structure of dextrin or ODEX, as observed by linkage analysis.

All samples displayed a peak at 10 min assigned to acidic oligosaccharides. However, it is possible that such peak does not correspond exclusively to acidic OS, since the analysis performed by $m$-phenylphenol, a colorimetric assay specific for uronic acids was negative for all samples. In addition, ESI-MS and MALDI-MS spectra revealed very few acidic OS possessing carboxylic or carbonyl groups in hemiacetal form, present in trace amounts. It is known that the aldehyde groups formed during oxidation react with neighbour hydroxyl groups, forming hemiacetals, in water. These transitory events could be either intra or inter-residue $[11,27,48,49]$. As the dextrin and ODEX samples were dissolved in PBS buffer, such ions interacted with the LEX/SEC 
(A) Dextrin

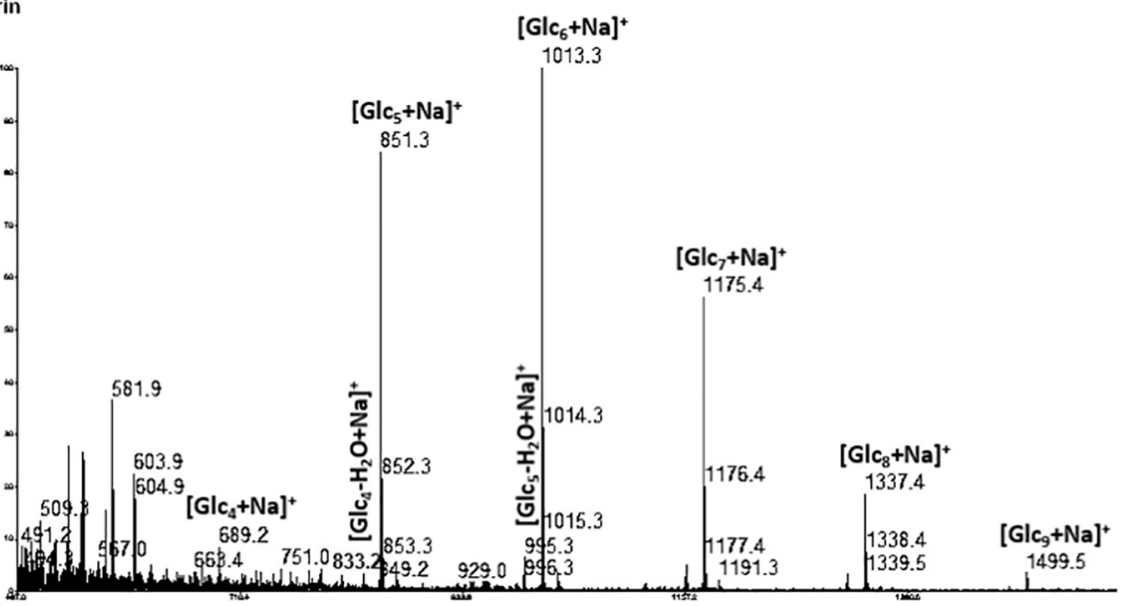

(B) ODEX

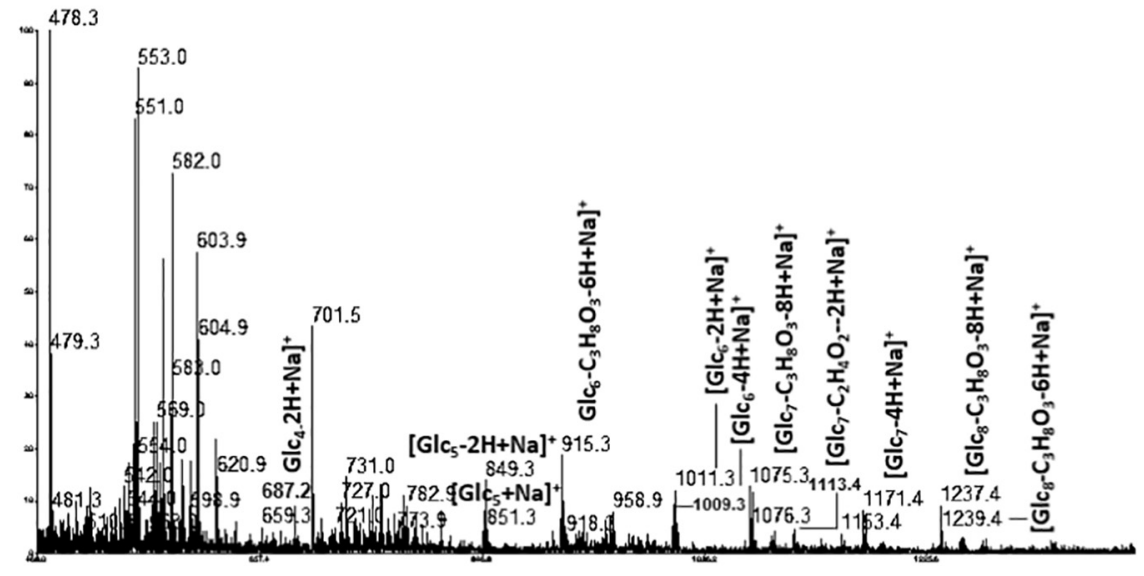

(C) ODEX $20 \mathrm{kGY}$

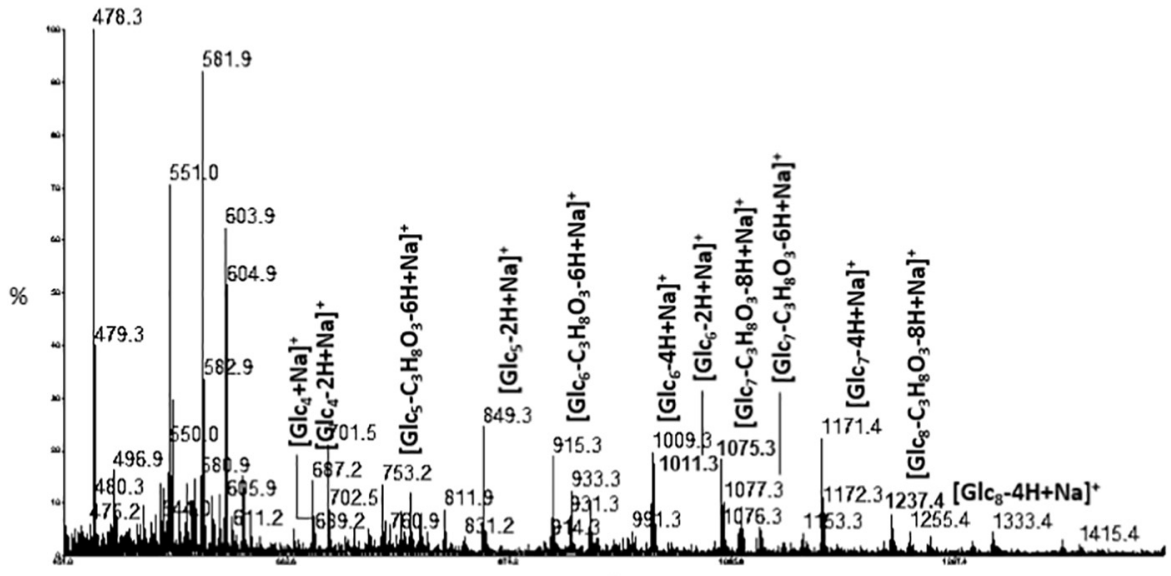

$\mathrm{m} / \mathrm{z}$

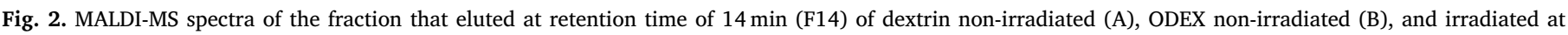
20 kGy (C).

matrix, eluting at the same retention time as the acidic OS. Therefore, only the MS spectra of the neutral fraction will be discussed in detail.

\subsection{Characterization of oligosaccharides from dextrin and ODEX samples by mass spectrometry}

The structural changes of dextrin associated to partial periodate oxidation and gamma irradiation were studied by MS using different ionization techniques: ESI and MALDI-MS. Analyses of oligosaccharides fractions with higher molecular weight were performed by MALDI-MS, since usually it generates only monocharged ions for larger molecules, unlike ESI-MS where multiple charged ions are commonly observed in this case [67]. Thus, the fractions F14 were analyzed by MALDI-MS. On the contrary, fractions F19 were analyzed only by ESI-MS and not by MALDI-MS due to the interference of the ions formed during the matrix ionization in the observation of low molecular weight oligosaccharides (DP lower than 3). Finally, fractions F17 were analyzed by MALDI- and ESI-MS. The oligosaccharides were observed in a positive mode as [M 
(A) Dextrin

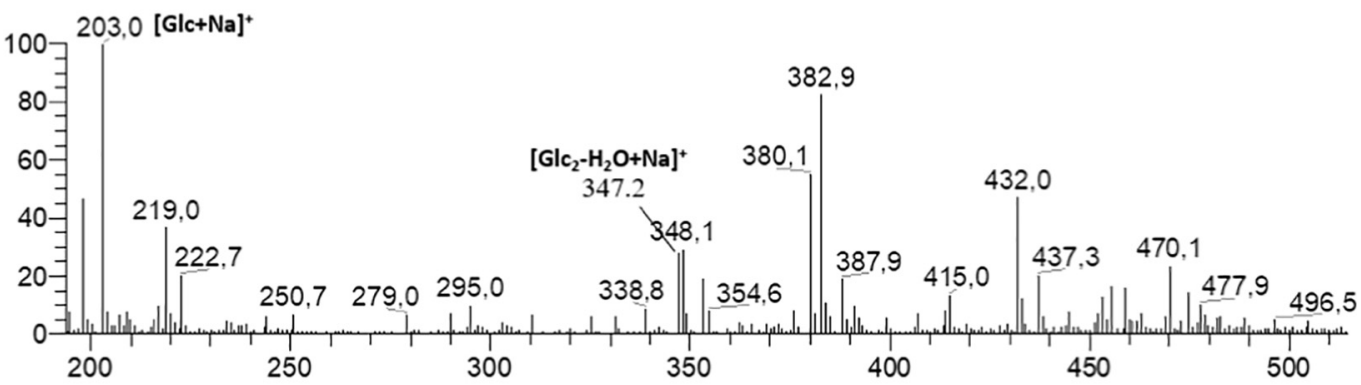

(B) ODEX

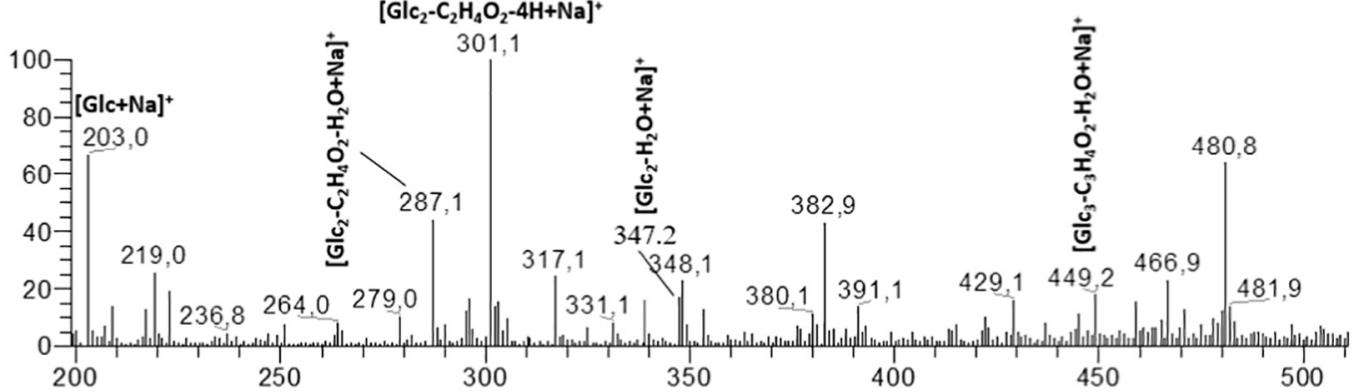

(C) ODEX $20 \mathrm{kGy}$

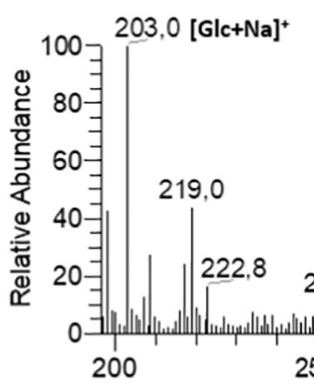

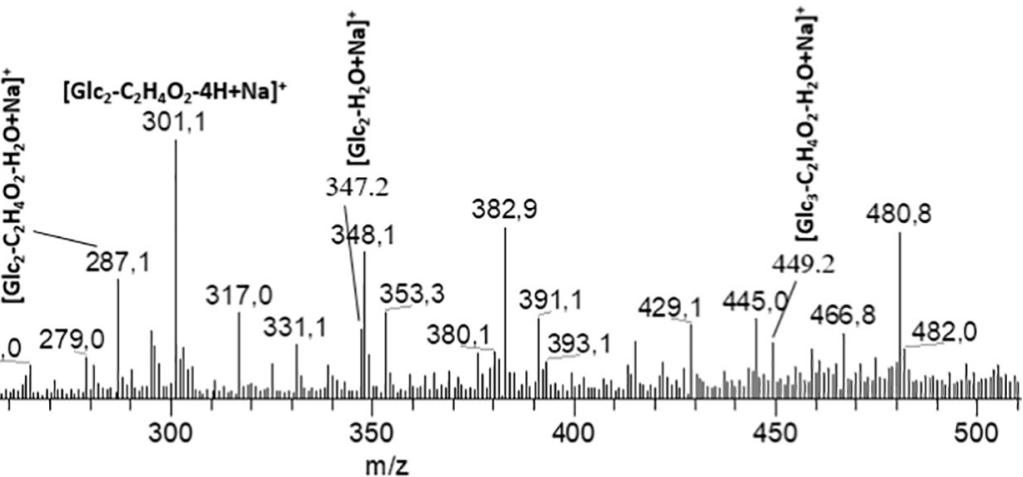

Fig. 3. ESI-MS spectra of the fraction eluted at $19 \mathrm{~min}$ (F19) of dextrin non-irradiated (A), ODEX non-irradiated (B), and irradiated at $20 \mathrm{kGy}$ (C).

$+\mathrm{Na}]^{+}$ions; as Glc was the only sugar detected by sugar and methylation analysis, the hexoses detected were all attributed to glucose.

\subsubsection{Neutral fractions from dextrin samples}

The selected fractions collected from LEX/SEC chromatography of dextrin non-irradiated and irradiated at $10 \mathrm{kGy}$ and at $20 \mathrm{kGy}$ were analyzed, for further comparison with the oxidized ones, as well as to study the impact of gamma irradiation. The neutral series of ions observed in the fractions F14, F17, and F19 of the dextrin samples were analysed. For each fraction, the MS spectra acquired were similar among all dextrin samples (irradiated and non-irradiated ones), confirming that gamma irradiation, under the tested conditions, did not affect the chemical structure of dextrin.

In all spectra of F14, F17, and F19, the major ions observed in dextrin (irradiated and non-irradiated samples) can be attributed to the sodium adducts of a series of hexose oligosaccharides ( $\mathrm{Glc}_{\mathrm{n}}$ ), bearing from one to nine glucose residues $\left(\left[\mathrm{Glc}_{\mathrm{n}}+\mathrm{Na}\right]^{+}, \mathrm{n}=[1-9]\right)$. Small ions were also observed that may be attributed to $\mathrm{Glc}_{\mathrm{n}}$ with less $18 \mathrm{Da}$, correspondent to dehydrated derivatives, $\left[\mathrm{Glc}_{\mathrm{n}}-\mathrm{H}_{2} \mathrm{O}+\mathrm{Na}\right]^{+}$ $(\mathrm{n}=[2-8])$. A representative MALDI-MS spectrum for $\mathrm{F} 14$ is presented in Fig. 2A and a representative ESI-MS spectrum for F19 in Fig. 3A, both corresponding to non-irradiated dextrin.

The ions belonging to $\left[\mathrm{Glc}_{\mathrm{n}}+\mathrm{Na}\right]^{+}$series are in accordance with that expected from the action of $\alpha$-amylase on dextrin samples, and corroborate the sugar and linkage analyses. The minor series observed, $\left[\mathrm{Glc}_{\mathrm{n}}-\mathrm{H}_{2} \mathrm{O}+\mathrm{Na}\right]^{+}$, as reported by Moreira et al. $[67,68]$, which also observed dehydration products using MS-based techniques for carbohydrate analysis, may be attributed to the presence of the anomeric carbon at the reducing terminal.

\subsubsection{Neutral fractions from ODEX samples}

For the oxidized samples (ODEX), the fractions F14 and F19 were analyzed by MALDI-MS and ESI-MS, respectively. The neutral oxidation series of ions observed of both ODEX samples and the proposed assignments were summarized in Table 3. These fractions, mainly F14, allowed to identify chemical modifications resultant from partial periodate oxidation. The MS spectra of ODEX non-irradiated (Fig. 2B and 3B) were very similar to those of the irradiated ones (Fig. 2C and 3C), displaying the same series of ions, also corroborating that gamma irradiation did not promote additional chemical modifications on ODEX structure. These results are very relevant, since as aldehydes are very reactive groups, it was hypothesized that irradiation could promote the formation of oxygen reactive species that could originate new chemical species by reacting with ODEX. For instance, some studies performed in carbohydrates subjected to oxidation with $\mathrm{HO}^{\circ}$ generated under Fenton reaction conditions $\left(\mathrm{Fe}^{2+} / \mathrm{H}_{2} \mathrm{O}_{2}\right)$ demonstrated the formation of new chemical species resulted from insertion of oxygen, and the occurrence of oxidative ring scission [38-40]. However, the formations of such 
Table 3

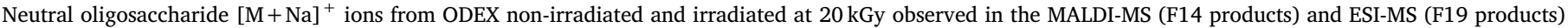
spectra, with the identification of the $m / z$ value and the proposed assignments.

\begin{tabular}{|c|c|c|c|c|c|c|c|c|c|c|}
\hline$n$ & $\left({ }^{*}\right)$ & 1 & 2 & 3 & 4 & 5 & 6 & 7 & 8 & 9 \\
\hline $\mathrm{Glc}_{\mathrm{n}}$ & $(0)$ & $203^{\#}$ & 365 & - & 689 & 851 & 1013 & - & - & - \\
\hline $\mathrm{Glc}_{\mathrm{n}}-2 \mathrm{H}$ & $(-2)$ & - & - & - & 687 & 849 & 1011 & 1173 & $1335^{\mathrm{a}}$ & - \\
\hline $\mathrm{Glc}_{\mathrm{n}}-4 \mathrm{H}$ & $(-4)$ & - & - & - & $685^{\mathrm{b}}$ & 847 & 1009 & 1171 & $1333^{\mathrm{a}}$ & - \\
\hline $\mathrm{Glc}_{\mathrm{n}}-6 \mathrm{H}$ & $(-6)$ & - & - & - & - & - & - & $1169^{\mathrm{a}}$ & $1331^{\mathrm{a}}$ & - \\
\hline $\mathrm{Glc}_{\mathrm{n}}-\mathrm{H}_{2} \mathrm{O}$ & $(-18)$ & - & 347 & - & - & - & - & - & - & - \\
\hline $\mathrm{Glc}_{\mathrm{n}}-\mathrm{H}_{2} \mathrm{O}-2 \mathrm{H}$ & $(-20)$ & - & - & - & $669^{\mathrm{a}}$ & $831^{\mathrm{a}}$ & 993 & 1155 & - & - \\
\hline $\mathrm{Glc}_{\mathrm{n}}-\mathrm{H}_{2} \mathrm{O}-4 \mathrm{H}$ & $(-22)$ & - & - & - & - & $829^{a}$ & $991^{\mathrm{a}}$ & 1153 & - & - \\
\hline $\mathrm{Glc}_{\mathrm{n}}-\mathrm{H}_{2} \mathrm{O}-6 \mathrm{H}$ & $(-24)$ & & - & - & - & - & - & $1151^{\mathrm{a}}$ & - & - \\
\hline $\mathrm{Glc}_{\mathrm{n}}-\mathrm{CH}_{4} \mathrm{O}-2 \mathrm{H}$ & $(-34)$ & - & - & - & - & - & 979 & - & - & - \\
\hline $\mathrm{Glc}_{\mathrm{n}}-\mathrm{CH}_{4} \mathrm{O}-8 \mathrm{H}$ & $(-40)$ & - & - & - & - & - & - & $1135^{\mathrm{a}}$ & - & - \\
\hline $\mathrm{Glc}_{\mathrm{n}}-\mathrm{CH}_{4} \mathrm{O}-10 \mathrm{H}$ & $(-42)$ & - & - & - & - & - & - & $1133^{\mathrm{a}}$ & - & - \\
\hline $\mathrm{Glc}_{\mathrm{n}}-\mathrm{C}_{2} \mathrm{H}_{4} \mathrm{O}_{2}-2 \mathrm{H}$ & $(-62)$ & - & 303 & 465 & 627 & - & 951 & 1113 & 1275 & - \\
\hline $\mathrm{Glc}_{\mathrm{n}}-\mathrm{C}_{2} \mathrm{H}_{4} \mathrm{O}_{2}-4 \mathrm{H}$ & $(-64)$ & - & 301 & - & - & - & 949 & 1111 & 1273 & - \\
\hline $\mathrm{Glc}_{\mathrm{n}}-\mathrm{C}_{2} \mathrm{H}_{4} \mathrm{O}_{2}-6 \mathrm{H}$ & $(-66)$ & - & - & - & - & - & - & $1009^{\mathrm{a}}$ & 1271 & - \\
\hline $\mathrm{Glc}_{\mathrm{n}}-\mathrm{C}_{2} \mathrm{H}_{4} \mathrm{O}_{2}-8 \mathrm{H}$ & $(-68)$ & - & - & - & - & - & - & - & $1269^{\mathrm{b}}$ & - \\
\hline $\mathrm{Glc}_{\mathrm{n}}-\mathrm{C}_{2} \mathrm{H}_{4} \mathrm{O}_{2}-\mathrm{H}_{2} \mathrm{O}$ & $(-78)$ & - & 287 & 449 & 611 & - & - & $1097^{\mathrm{a}}$ & - & - \\
\hline $\mathrm{Glc}_{\mathrm{n}}-\mathrm{C}_{2} \mathrm{H}_{4} \mathrm{O}_{2}-\mathrm{H}_{2} \mathrm{O}-2 \mathrm{H}$ & $(-80)$ & - & - & - & $609^{a}$ & 771 & 933 & 1095 & 1257 & - \\
\hline $\mathrm{Glc}_{\mathrm{n}}-\mathrm{C}_{2} \mathrm{H}_{4} \mathrm{O}_{2}-\mathrm{H}_{2} \mathrm{O}-4 \mathrm{H}$ & $(-82)$ & - & - & 445 & - & - & $931^{\mathrm{a}}$ & 1093 & 1255 & - \\
\hline $\mathrm{Glc}_{\mathrm{n}}-\mathrm{C}_{2} \mathrm{H}_{4} \mathrm{O}_{2}-\mathrm{H}_{2} \mathrm{O}-6 \mathrm{H}$ & $(-84)$ & - & - & 443 & - & - & - & 1091 & 1253 & - \\
\hline $\mathrm{Glc}_{\mathrm{n}}-\mathrm{C}_{3} \mathrm{H}_{8} \mathrm{O}_{3}-4 \mathrm{H}$ & $(-96)$ & - & - & - & $593^{\mathrm{b}}$ & 755 & 917 & 1079 & 1241 & - \\
\hline $\mathrm{Glc}_{\mathrm{n}}-\mathrm{C}_{3} \mathrm{H}_{8} \mathrm{O}_{3}-6 \mathrm{H}$ & $(-98)$ & - & - & - & - & 753 & 915 & 1077 & 1239 & $1401^{\mathrm{a}}$ \\
\hline $\mathrm{Glc}_{\mathrm{n}}-\mathrm{C}_{3} \mathrm{H}_{8} \mathrm{O}_{3}-8 \mathrm{H}$ & $(-100)$ & - & - & - & - & - & 913 & 1075 & 1237 & $1399^{\mathrm{a}}$ \\
\hline $\mathrm{Glc}_{\mathrm{n}}-\mathrm{C}_{3} \mathrm{H}_{8} \mathrm{O}_{3}-10 \mathrm{H}$ & $(-102)$ & - & - & - & - & - & - & - & $1235^{\mathrm{a}}$ & $1397^{\mathrm{a}}$ \\
\hline
\end{tabular}

* Values in brackets are the $m / z$ value differences compared to the $\left[\mathrm{Glc}_{\mathrm{n}}+\mathrm{Na}\right]^{+}$ions.

\# The ions in bold were also observed in all dextrin samples.

a Not observed in ODEX non-irradiated spectrum.

b Not observed in ODEX irradiated at $20 \mathrm{kGy}$ spectrum.

chemical species after ODEX irradiation was not observed in MS spectra, by comparison with ODEX non-irradiated spectra.

In the MALDI-MS spectra of the ODEX samples (Fig. 2B and C), it was possible to observe that the relative abundance of ions of unmodified oligosaccharides $\left(\left[\mathrm{Glc}_{\mathrm{n}}+\mathrm{Na}\right]^{+}\right.$series) decreased significantly as compared to dextrin (Fig. 2A), and several new ions were observed. Relating to $\left[\mathrm{Glc}_{\mathrm{n}}-\mathrm{H}_{2} \mathrm{O}+\mathrm{Na}\right]^{+}$series in dextrin samples, only the ions at $\mathrm{m} / \mathrm{z} 347$ were observed in ESI-MS spectrum (Table 3), assigned as [ $\mathrm{Glc}_{2^{-}}$ $\left.\mathrm{H}_{2} \mathrm{O}+\mathrm{Na}\right]^{+}$. The new ions observed in MALDI- and ESI-MS could be attributed to oxidized oligosaccharides resulting from partial periodate oxidation process and will be described below.

The new ions observed in MALDI- and ESI-MS spectra of both ODEX samples allowed to identify ions belonging to the series with less $2 \mathrm{Da}$, $4 \mathrm{Da}$ and $6 \mathrm{Da}$ than the $\left[\mathrm{Glc}_{\mathrm{n}}+\mathrm{Na}\right]^{+}$series, assigned, respectively, as $\left[\mathrm{Glc}_{\mathrm{n}}-2 \mathrm{H}+\mathrm{Na}\right]^{+},\left[\mathrm{Glc}_{\mathrm{n}}-4 \mathrm{H}+\mathrm{Na}\right]^{+}(\mathrm{n}=[4-8])$ and $\left[\mathrm{Glc}_{\mathrm{n}}-6 \mathrm{H}+\mathrm{Na}\right]^{+}$ $(n=[7,8])$. These products must correspond to the oxidation of one, two or three residues of glucose of the oligosaccharides, respectively. Periodate oxidation occurs by the attack of periodate ion $\left(\mathrm{IO}_{4}{ }^{-}\right)$specifically to vicinal diols, breaking the carbon-carbon bond and yielding two aldehyde groups [11]. As dextrin is mainly composed by $(1 \rightarrow 4)$ Glc, it only contains a vicinal diol at C2-C3, which in turn can be attacked by one periodate ion, forming aldehyde groups at $\mathrm{C} 2$ and $\mathrm{C} 3$ with loss of two hydrogens $(-2 \mathrm{H})$ per oxidized hexose (Supplementary Fig. S1-A). For instance, the product ions at $m / z 1011$ and 1009 present in the F14 of ODEX spectra (Fig. 2B and C) resulted from the formation of two $\left(\left[\mathrm{Glc}_{6}-2 \mathrm{H}+\mathrm{Na}\right]^{+}\right)$or four $\left(\left[\mathrm{Glc}_{6}-4 \mathrm{H}+\mathrm{Na}\right]^{+}\right)$aldehydes groups, corresponding to the oxidation of one and two $(1 \rightarrow 4)$-linked residues of the oligosaccharides, respectively. It was also identified dehydrated oligosaccharides with loss of $2 \mathrm{Da}\left(\left[\mathrm{Glc}_{\mathrm{n}}-\mathrm{H}_{2} \mathrm{O}-2 \mathrm{H}+\mathrm{Na}\right]^{+}, \mathrm{n}=[4-7]\right)$, $4 \mathrm{Da}\left(\left[\mathrm{Glc}_{\mathrm{n}}-\mathrm{H}_{2} \mathrm{O}-4 \mathrm{H}+\mathrm{Na}\right]^{+}, \mathrm{n}=[5-7]\right)$, and one ion $(\mathrm{m} / z$ 1151) with loss of $6 \mathrm{Da}$, assigned as $\left[\mathrm{Glc}_{7}-\mathrm{H}_{2} \mathrm{O}-6 \mathrm{H}+\mathrm{Na}\right]^{+}$.
Other series of neutral oxidation products were identified as resulting from oxidative ring scissions reactions on terminal and branched residues. Non-reducing and reducing terminals, as well as, $(1 \rightarrow 4,6)$ Glc residues, contain hydroxyl groups on each of three adjacent carbon atoms, which can be oxidized by 2 periodate ions, with the release of formic acid (HCOOH) [11]. Thus, the ions observed with less $60 \mathrm{Da}$ than the $\left[\mathrm{Glc}_{\mathrm{n}}+\mathrm{Na}\right]^{+}$series, revealed by the ions at $\mathrm{m} / \mathrm{z} 305,629,953$ and 1115 , were assigned to $\left[\mathrm{Glc}_{\mathrm{n}}-\mathrm{C}_{2} \mathrm{H}_{4} \mathrm{O}_{2}+\mathrm{Na}\right]^{+}(\mathrm{n}=2,4,6-7)$ and resulted from the oxidation of the reducing terminal of dextrin. At this terminal, C1-C2 and C2-C3 bonds could be attacked by two periodate ions, with the formation of an aldehyde at $\mathrm{C} 3$ position [11,69], leading to the formation of $\left(\mathrm{Glc}_{\mathrm{n}}-\mathrm{C}_{2} \mathrm{H}_{4} \mathrm{O}_{2}\right)$ species (Supplementary Fig. S1-B). Oxidized oligosaccharides formed by carbon-carbon cleavage at reducing terminal can also display oxidative cleavages between $\mathrm{C} 2-\mathrm{C} 3$ at $(1 \rightarrow 4)$-Glc $\left(\left[\mathrm{Glc}_{\mathrm{n}}-\mathrm{C}_{2} \mathrm{H}_{4} \mathrm{O}_{2}-\mathrm{mH}+\mathrm{Na}\right]^{+} ; \mathrm{n}=[2-8] ; \mathrm{m}=[2-8]\right)$. For example, the ion at $m / z 1113$, observed in the MALDI-MS spectra of ODEX, can be attributed to oligosaccharide modified at the reducing terminal $\left(-\mathrm{C}_{2} \mathrm{H}_{4} \mathrm{O}_{2}\right)$ and with other modification in another glucose residue $(-2 \mathrm{H})$, leading to $\left[\mathrm{Glc}_{7}-\mathrm{C}_{2} \mathrm{H}_{4} \mathrm{O}_{2}-2 \mathrm{H}+\mathrm{Na}\right]^{+}$.

The ion series with less $32 \mathrm{Da}$ than the $\left[\mathrm{Glc}_{\mathrm{n}}+\mathrm{Na}\right]^{+}$series were assigned to $\left[\mathrm{Glc}_{\mathrm{n}}-\mathrm{CH}_{4} \mathrm{O}+\mathrm{Na}\right]^{+}(\mathrm{n}=5-6)$ and could be attributed to the oxidation of the non-reducing terminal or the $(1 \rightarrow 4,6)$-Glc. At these residues, two periodate ions can attack the hydroxyl groups between C3-C4 and C2-C3 bonds. During these reactions occur the formation of aldehyde groups at $\mathrm{C} 2$ and $\mathrm{C} 4$ positions, and $\mathrm{C} 3$ is eliminated as formic acid $[11,70]$, generating $\left(\mathrm{Glc}_{\mathrm{n}}-\mathrm{CH}_{4} \mathrm{O}\right)$ species (Supplementary Fig. S1C). For this series, the possibility of additional oxidation of other glucose residues was also observed, by the oxidative cleavage between C2$\mathrm{C} 3$ of one $(-2 \mathrm{Da})$, four $(-8 \mathrm{Da})$ or five $(-10 \mathrm{Da})$ residues, as revealed by the ions at $m / z 979,1135$ and 1133 , respectively.

An ion series with less $92 \mathrm{Da}$ than the $\left[\mathrm{Glc}_{n}+\mathrm{Na}\right]^{+}$was observed 
(A) ESI-MS/MS - 305
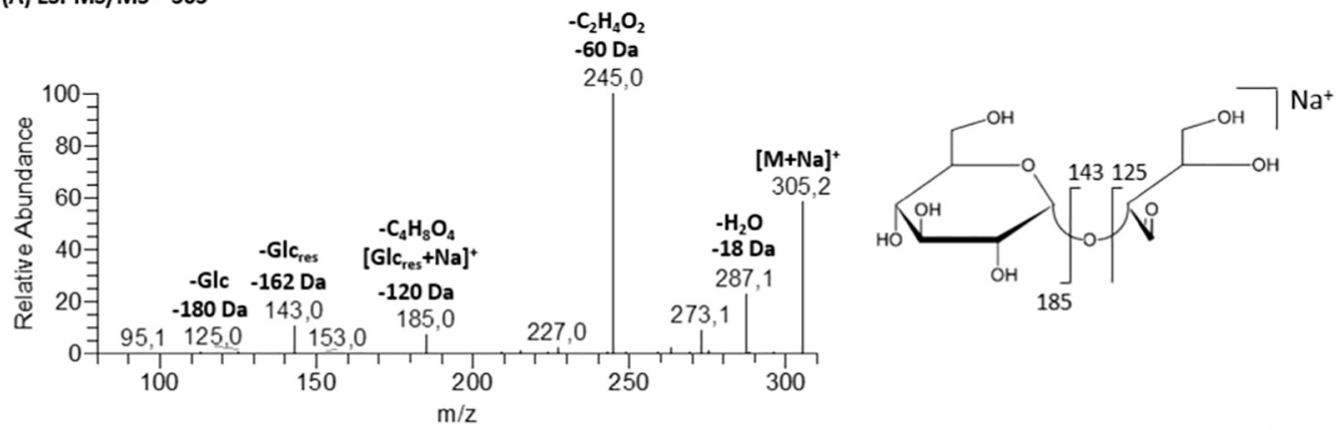

(B) ESI-MS/MS - 303
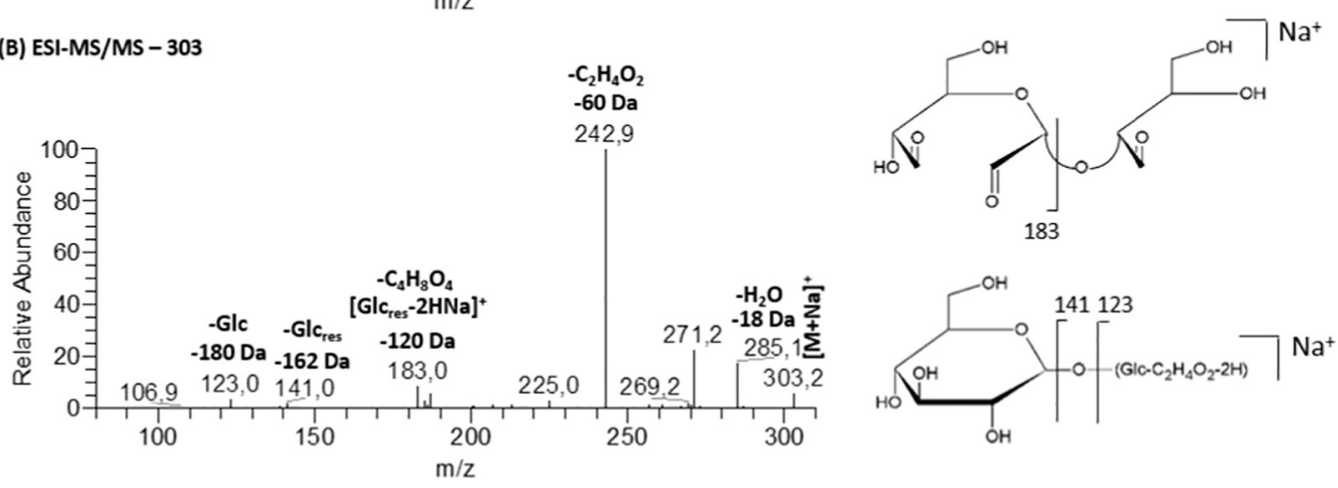

(C) ESI-MS/MS - 301
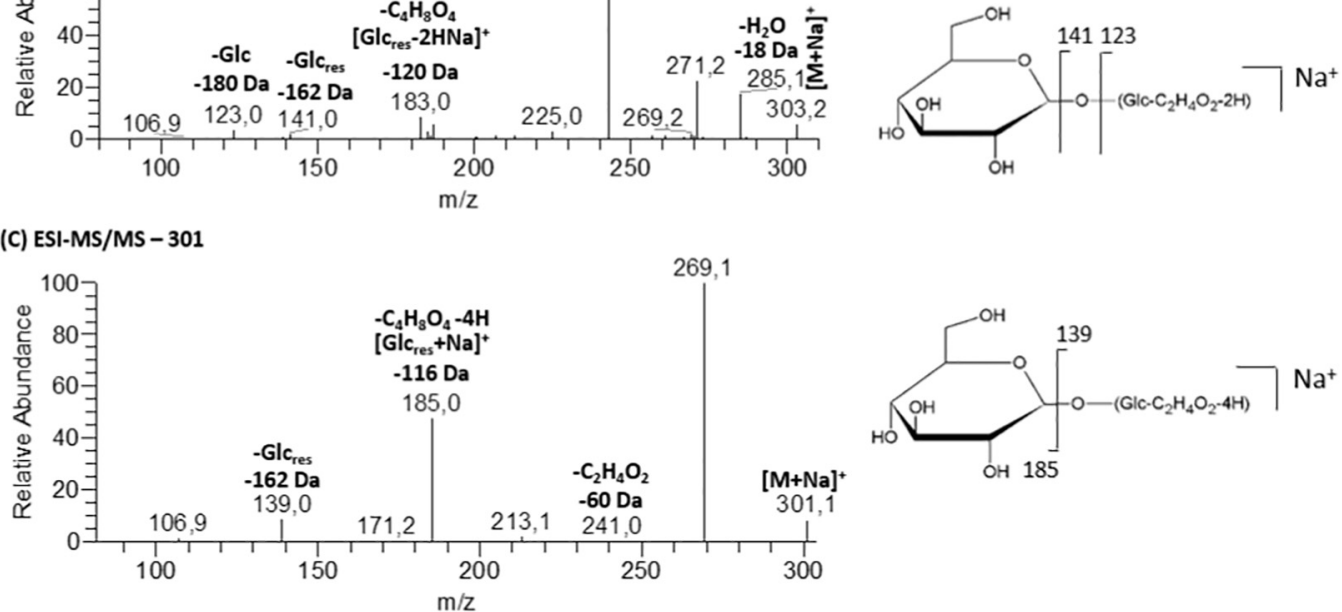

(D) ESI-MS/MS - 465
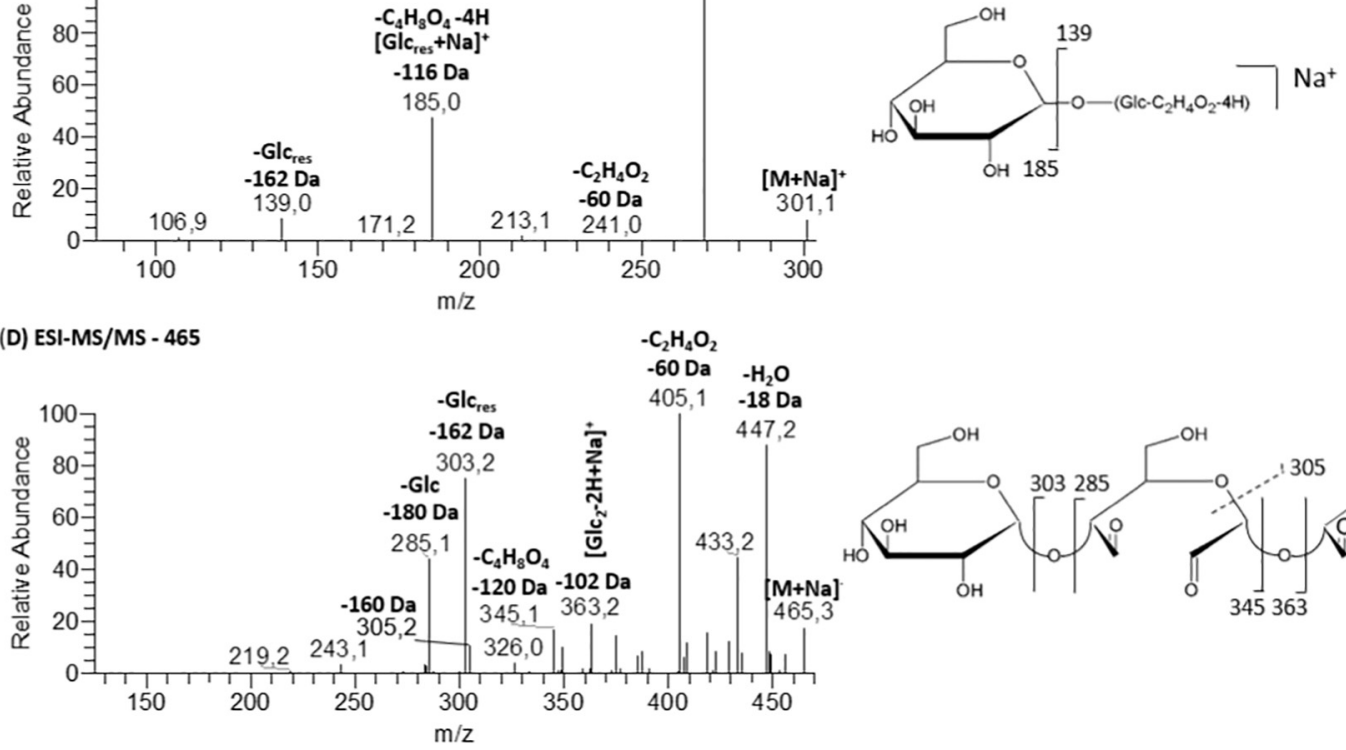

Fig. 4. ESI-MS/MS spectra and schematic fragmentation pathways of $[\mathrm{M}+\mathrm{Na}]^{+}$ions identified after periodate oxidation of the dextrin: $(\mathrm{A})\left[\mathrm{Glc}_{2}-\mathrm{C}_{2} \mathrm{H}_{4} \mathrm{O}_{2}+\mathrm{Na}^{+}\right.$; $(\mathrm{B})$ $\left[\mathrm{Glc}_{2}-\mathrm{C}_{2} \mathrm{H}_{4} \mathrm{O}_{2}-2 \mathrm{H}+\mathrm{Na}\right]^{+}$; (C) $\left[\mathrm{Glc}_{2}-\mathrm{C}_{2} \mathrm{H}_{4} \mathrm{O}_{2}-4 \mathrm{H}+\mathrm{Na}\right]^{+}$; (D) $\left[\mathrm{Glc}_{3}-\mathrm{C}_{2} \mathrm{H}_{4} \mathrm{O}_{2}-2 \mathrm{H}+\mathrm{Na}\right]^{+}$.

and could be attributed to the oxidation of both terminal residues by periodate ions. For instance, the ion with $\mathrm{m} / \mathrm{z} 597$, observed in the MALDI-MS spectrum of ODEX irradiated at $20 \mathrm{kGy}$, can arise from oligosaccharides modified at the reducing $\left(-\mathrm{C}_{2} \mathrm{H}_{4} \mathrm{O}_{2}\right)$ and non-reducing $\left(-\mathrm{CH}_{4} \mathrm{O}\right)$ terminals, leading to $\left[\mathrm{Glc}_{4}-\mathrm{C}_{3} \mathrm{H}_{8} \mathrm{O}_{3}+\mathrm{Na}\right]^{+}$. Oligosaccharides with both oxidized terminals can also present oxidative cleavages between C2-C3 at $(1 \rightarrow 4)$-Glc $\left(\left[\mathrm{Glc}_{\mathrm{n}}-\mathrm{C}_{3} \mathrm{H}_{8} \mathrm{O}_{3}-\mathrm{mH}+\mathrm{Na}\right]^{+} ; \mathrm{n}=[4-9]\right.$; $\mathrm{m}=[4-10])$.

3.4.3. Identification of structural features in oligosaccharides by tandem mass spectrometry

In order to confirm the structural features based on the MS spectra, all the oligosaccharides observed in ESI-MS from F19 were also analyzed by ESI-MS/MS. In this fraction, the only ions observed as a result of partial periodate oxidation process are belonging to series $\mathrm{Glc}_{\mathrm{n}}$ $\mathrm{C}_{2} \mathrm{H}_{4} \mathrm{O}_{2}, \mathrm{Glc}_{\mathrm{n}}-\mathrm{C}_{2} \mathrm{H}_{4} \mathrm{O}_{2}-2 \mathrm{H}$ and $\mathrm{Glc}_{\mathrm{n}}-\mathrm{C}_{2} \mathrm{H}_{4} \mathrm{O}_{2}-4 \mathrm{H}$, whose product ion spectra (ESI-MS/MS) will be described in detailed.

Previous studies performed on the fragmentation of $[\mathrm{M}+\mathrm{Na}]^{+}$ions of hexose oligosaccharides under ESI-MS/MS conditions exhibited a characteristic predominant loss of water ( $-18 \mathrm{Da})$, and loss of a hexose residue (here represented as $\mathrm{Glc}_{\text {res}},-162 \mathrm{Da}$ ), due to glycosidic bond cleavage $[38,67]$. Additionally, the cross-ring cleavages (cleavage of two bonds within the sugar ring) with loss of $60 \mathrm{Da}\left(-\mathrm{C}_{2} \mathrm{H}_{4} \mathrm{O}_{2}\right)$, typical for $(1 \rightarrow 4)$-linked Glc units, were also detected [36].

The ion at $m / z 305$ observed in the ESI-MS/MS of ODEX samples (irradiated and non-irradiated), may correspond to [ $\mathrm{Glc}_{2}{ }^{-}$ $\left.\mathrm{C}_{2} \mathrm{H}_{4} \mathrm{O}_{2}+\mathrm{Na}\right]^{+}$. The formation of this product can be attributed to the oxidation of the reducing terminal. The ESI-MS/MS spectrum (Fig. 4A) 
showed the product ion at $m / z 185$, assigned to $\left[\mathrm{Glc}_{\mathrm{res}}+\mathrm{Na}\right]^{+}$, formed due to the loss of $120 \mathrm{Da}$, indicating that this oligosaccharide bears an unmodified glucose and a tetrose $\left(\mathrm{C}_{4} \mathrm{H}_{8} \mathrm{O}_{4}\right)$. The presence of the tetrose resulted from the oxidative ring scission between $\mathrm{C} 2$ and $\mathrm{C} 3$ of the reducing terminal (loss of $\mathrm{C}_{2} \mathrm{H}_{4} \mathrm{O}_{2}$ ), promoted by periodate. The product ions at $m / z 125$ and 143 are due to the loss of a Glc and Glc res, respectively, confirming also that this oligosaccharide is composed by a glucose linked to a tetrose.

The product ion at $m / z 303\left(\left[\mathrm{Glc}_{2}-\mathrm{C}_{2} \mathrm{H}_{4} \mathrm{O}_{2}-2 \mathrm{H}+\mathrm{Na}\right]^{+}\right)$is present in small abundance in ESI-MS spectra of the ODEX samples (irradiated and non-irradiated). The ESI-MS/MS spectrum of this ion (Fig. 4B) showed the product ion at $m / z 183$, assigned to $\left[\mathrm{Glc}_{\mathrm{res}}-2 \mathrm{H}+\mathrm{Na}\right]^{+}$due to loss of $120 \mathrm{Da}$, indicating the presence of an oxidized hexose $(-2 \mathrm{H})$. The loss of $120 \mathrm{Da}\left(-\mathrm{C}_{4} \mathrm{H}_{8} \mathrm{O}_{4}\right)$ from the precursor ion allows to infer also that this oligosaccharide bears a tetrose at the reducing terminal, resulting from the oxidation $\left(-\mathrm{C}_{2} \mathrm{H}_{4} \mathrm{O}_{2}\right)$ of the initial glucose, promoted by periodate. However, the ions identified at $m / z 123$ (-Glc) and 141 (-Glc res $_{\text {r }}$ ) indicate the presence of another isomer with one intact glucose, so that the loss of $2 \mathrm{H}$ may occur at the reducing terminal (tetrose-2H). The trace abundance of these ions can indicate that such isomer might be present in smaller abundance, and it is possible that the reducing terminal of dextrin was already oxidized before the periodate oxidation reaction performed.

The ion at $m / z 301$ is one of the most prominent ions in the ESI-MS spectra of the ODEX samples (irradiated and non-irradiated) and can be attributed to $\left[\mathrm{Glc}_{2}-\mathrm{C}_{2} \mathrm{H}_{4} \mathrm{O}_{2}-4 \mathrm{H}+\mathrm{Na}\right]^{+}$. The ESI-MS/MS spectrum (Fig. 4C) showed the product ions at $\mathrm{m} / z 139$ (-Glc $\mathrm{Cres}_{\text {res }}$ ) and 185 ([Glc $+\mathrm{Na}]^{+}$) which confirm the presence of an intact glucose residue. The loss of $116 \mathrm{Da}$ from the precursor ion suggests that this oligosaccharide bears a modified tetrose at the reducing terminal (tetrose-4H). However, the absence of other peaks hinders the identification of the exact locations of the loss of $4 \mathrm{H}$.

The ion at $m / z 465$ is present in ESI-MS spectra of the ODEX samples (irradiated and non-irradiated) in residual abundance and was assigned to an oligosaccharide bearing a tetrose as a result of oxidation of the reducing terminal, and with one $(1 \rightarrow 4)$-Glc residue oxidized ([Glc $3_{3^{-}}$ $\left.\mathrm{C}_{2} \mathrm{H}_{4} \mathrm{O}_{2}-2 \mathrm{H}+\mathrm{Na}\right]^{+}$). The ESI-MS/MS spectrum (Fig. 4D) showed the ion at $m / z 363$, assigned to $\left[\mathrm{Glc}_{2}-2 \mathrm{H}+\mathrm{Na}\right]^{+}$, indicating that one glucose suffered an oxidative ring scission at C3-C4 bond. The ions at $\mathrm{m} / \mathrm{z}$ $303(-162 \mathrm{Da})$ and at $m / z 285(-180 \mathrm{Da})$, formed by loss of a $\mathrm{Glc}_{\mathrm{res}}$ and Glc, respectively, indicate that the non-reducing terminal is composed by an unmodified glucose and the oxidative ring scission occurred in the middle of the oligosaccharide, originating aldehyde groups at C2 and C3, as confirmed by ion at $m / z$ 305. The products ions at $m / z 345$ and 363 , corresponding to the loss of $120 \mathrm{Da}$ and $102 \mathrm{Da}$ respectively, confirm that oligosaccharide contains a tetrose $\left(\mathrm{C}_{4} \mathrm{H}_{8} \mathrm{O}_{4}\right)$ at the reducing terminal caused by oxidative ring scission between $\mathrm{C} 2$ and $\mathrm{C} 3$ (loss of $\mathrm{C}_{2} \mathrm{H}_{4} \mathrm{O}_{2}$ ) promoted by periodate.

\section{Conclusions}

In this study, different MS-based techniques (MALDI-MS, ESI-MS and ESI-MS/MS) were used, for the first time, for identification and characterization of dextrin structural modifications related to partial periodate oxidation. The results obtained confirmed that periodate ion is a glycol-cleaving oxidant highly selective, leading to formation of aldehydes groups. The results showed that during periodate oxidation reaction three major series of oxidation products are formed, according to the type of residue of the dextrin backbone which is attacked by periodate ion: i) the oxidation of $(1 \rightarrow 4)$-Glc residues leads to the formation of $\left.\left(\mathrm{Glc}_{\mathrm{n}}-\mathrm{mH} ; \mathrm{n}=[4-8] ; \mathrm{m}=[2-6]\right)\right)$ species; ii) the oxidation of reducing terminal residues, leads to the formation of $\left(\mathrm{Glc}_{\mathrm{n}}-\mathrm{C}_{2} \mathrm{H}_{4} \mathrm{O}_{2}\right.$; $\mathrm{n}=[5-7])$ species, and iii) the oxidation of non-reducing terminal or $(1 \rightarrow 4,6)$-Glc residues produces $\left(\mathrm{Glc}_{\mathrm{n}}-\mathrm{CH}_{4} \mathrm{O} ; \mathrm{n}=[2-8]\right)$ species. Oxidation products containing more than one type of residue oxidized were also identified.
Gamma irradiation is a commonly used method to sterilize biomaterials for biomedical applications. However, the impact of this sterilization procedure on the biomaterial structure/functionality has not been sufficiently addressed, in particular in the case of biological materials such as oxidized polysaccharides. In this study, it was demonstrated that gamma irradiation can be used as suitable terminal sterilization method for ODEX and dextrin related biomaterials. Indeed, sugars and glycosidic-linkage, as well as MS analysis showed that sterilizing gamma irradiation, under the tested conditions, did not promote changes on the chemical structure of dextrin or ODEX. It can be hypothesized that gamma irradiation will also not impact significantly the structure of other polysaccharides relevant in biomedicine, such as pullulan, alginate, cellulose and dextran.

\section{Acknowledgment}

Isabel Pereira was supported by the grant SFRH/BD/ 90066/2012 from Fundação para a Ciência e a Tecnologia (FCT), Portugal. The authors acknowledge the funding from QREN ("Quadro de Referência Estratégica Nacional"), ADI ("Agência de Inovação") through the project Norte-07-0202-FEDER-038853, and BioTecNorte operation (NORTE-01-0145-FEDER-000004) funded by the European Regional Development Fund under the scope of Norte2020-Programa Operacional Regional do Norte.

Also thanks to FCT/MEC Portugal for the financial support to the QOPNA research Unit (FCT UID/QUI/00062/2013), through national founds and where applicable co-financed by the FEDER, within the PT2020 Partnership Agreement, and RNEM (REDE/1504/REM/2005 that concerns the Portuguese Mass Spectrometry Network). Thanks, are also due to FCT for the grant of Joana Simões (SFRH/BPD/90447/ 2012).

\section{Appendix A. Supplementary material}

Supplementary data associated with this article can be found, in the online version, at https://doi.org/10.1016/j.eurpolymj.2018.04.011.

\section{References}

[1] C. Gonçalves, S.M. Moreira, V. Carvalho, D.M. Silva, M. Gama, Dextrin, in: M. Mishra (Ed.), Encycl. Biomed. Polym. Polym. Biomater., first ed., Taylor \& Francis, New York, 2016, pp. 2634-2649.

[2] D.M. Silva, C. Nunes, I. Pereira, A.S.P. Moreira, M.R.M. Domingues, M.A. Coimbra, F.M. Gama, Structural analysis of dextrins and characterization of dextrin-based biomedical hydrogels, Carbohydr. Polym. 114 (2014) 458-466, http://dx.doi.org/ 10.1016/j.carbpol.2014.08.009.

[3] P. Tomasik, S. Wiejak, M. Pałasiński, The thermal decomposition of carbohydrates. Part II. The decomposition of starch, Adv. Carbohydr. Chem. Biochem. (1989) 279-343, http://dx.doi.org/10.1016/S0065-2318(08)60416-3.

[4] E. Peers, R. Gokal, Icodextrin provides long dwell peritoneal dialysis and maintenance of intraperitoneal volume, Artif. Organs. 22 (1998) 8-12 (accessed August 17, 2016), http://www.ncbi.nlm.nih.gov/pubmed/9456219.

[5] Y. Takatori, S. Akagi, H. Sugiyama, J. Inoue, S. Kojo, H. Morinaga, K. Nakao, J. Wada, H. Makino, Icodextrin increases technique survival rate in peritoneal dialysis patients with diabetic nephropathy by improving body fluid management: a randomized controlled trial, Clin. J. Am. Soc. Nephrol. 6 (2011) 1337-1344, http:// dx.doi.org/10.2215/CJN.10041110.

[6] B. Treetharnmathurot, L. Dieudonné, E.L. Ferguson, D. Schmaljohann, R. Duncan, R. Wiwattanapatapee, Dextrin-trypsin and ST-HPMA-trypsin conjugates: enzyme activity, autolysis and thermal stability, Int. J. Pharm. 373 (2009) 68-76, http://dx. doi.org/10.1016/j.ijpharm.2009.02.008.

[7] A.O.V. DeBusk, T. Alleman, Method for preparing medical dressings, US 2006/ 0018955 A1, 2006

[8] D. Das, S. Pal, Modified biopolymer-dextrin based crosslinked hydrogels: application in controlled drug delivery, RSC Adv. 5 (2015) 25014-25050, http://dx.doi. org/10.1039/C4RA16103C.

[9] M. Molinos, V. Carvalho, D.M. Silva, F.M. Gama, Development of a hybrid dextrin hydrogel encapsulating dextrin nanogel as protein delivery system, Biomacromolecules 13 (2012) 517-527, http://dx.doi.org/10.1021/bm2015834.

[10] D.M. Silva, A.R. Caseiro, I. Amorim, I. Pereira, F. Faria, T. Pereira, J.D. Santos, F.M. Gama, A.C. Maurício, Inflammatory response to dextrin-based hydrogel associated with human mesenchymal stem cells, urinary bladder matrix and Bonelike ${ }^{\oplus}$ granules in rat subcutaneous implants, Biomed. Mater. 11 (2016) 65004, http://dx. doi.org/10.1088/1748-6041/11/6/065004. 
[11] A.S. Perlin, Glycol-cleavage oxidation, Adv. Carbohydr. Chem. Biochem. (2006) 183-250, http://dx.doi.org/10.1016/S0065-2318(06)60005-X.

[12] T. Takei, M. Sato, H. Ijima, K. Kawakami, In situ gellable oxidized citrus pectin for localized delivery of anticancer drugs and prevention of homotypic cancer cell aggregation, Biomacromolecules 11 (2010) 3525-3530, http://dx.doi.org/10. 1021/bm1010068.

[13] S. Xiao, X. Liu, C. Tong, L. Zhao, X. Liu, A. Zhou, Y. Cao, Dialdehyde starch nanoparticles as antitumor drug delivery system: an in vitro, in vivo, and immunohistological evaluation, Chinese Sci. Bull. 57 (2012) 3226-3232, http://dx. doi.org/10.1007/s11434-012-5342-5.

[14] M. Ragothaman, T. Palanisamy, C. Kalirajan, Collagen-poly(dialdehyde) guar gum based porous 3D scaffolds immobilized with growth factor for tissue engineering applications, Carbohydr. Polym. 114 (2014) 399-406, http://dx.doi.org/10.1016/j. carbpol.2014.08.045.

[15] J. Maia, L. Ferreira, R. Carvalho, M.A. Ramos, M.H. Gil, Synthesis and characterization of new injectable and degradable dextran-based hydrogels, Polymer (Guildf). 46 (2005) 9604-9614, http://dx.doi.org/10.1016/j.polymer.2005.07.089.

[16] C.G. Gomez, M. Rinaudo, M.A. Villar, Oxidation of sodium alginate and characterization of the oxidized derivatives, Carbohydr. Polym. 67 (2007) 296-304, http://dx.doi.org/10.1016/j.carbpol.2006.05.025.

[17] A. Potthast, M. Kostic, S. Schiehser, P. Kosma, T. Rosenau, Studies on oxidative modifications of cellulose in the periodate system: molecular weight distribution and carbonyl group profiles, Holzforschung 61 (2007) 662-667, http://dx.doi.org/ 10.1515/HF.2007.099.

[18] M. Rinaudo, Periodate oxidation of methylcellulose: characterization and properties of oxidized derivatives, Polymers (Basel). 2 (2010) 505-521, http://dx.doi.org/10. 3390/polym2040505.

[19] I.M.N. Vold, K.A. Kristiansen, B.E. Christensen, A study of the chain stiffness and extension of alginates, vitro epimerized alginates, and periodate-oxidized alginates using size-exclusion chromatography combined with light scattering and viscosity detectors, Biomacromolecules 7 (2006) 2136-2146, http://dx.doi.org/10.1021/ bm060099n.

[20] K.A. Kristiansen, H.B. Tomren, B.E. Christensen, Periodate oxidized alginates: depolymerization kinetics, Carbohydr. Polym. 86 (2011) 1595-1601, http://dx.doi org/10.1016/j.carbpol.2011.06.069.

[21] K.A. Kristiansen, M.Ø. Dalheim, B.E. Christensen, Periodate oxidation and macro molecular compaction of hyaluronan, Pure Appl. Chem. 85 (2013) 1893-1900, http://dx.doi.org/10.1351/pac-con-13-01-05.

[22] M. Fiedorowicz, A. Para, Structural and molecular properties of dialdehyde starch, Carbohydr. Polym. 63 (2006) 360-366, http://dx.doi.org/10.1016/j.carbpol.2005. 08.054 .

[23] S. Veelaert, M. Polling, D. De Wit, Structural and physicochemical changes of potato starch along periodate oxidation, Starch - Stärke 47 (1995) 263-268, http://dx.doi. org/10.1002/star.19950470706.

[24] B. Gupta, M. Tummalapalli, B.L. Deopura, M.S. Alam, Functionalization of pectin by periodate oxidation, Carbohydr. Polym. 98 (2013) 1160-1165, http://dx.doi.org/ 10.1016/j.carbpol.2013.06.069.

[25] B.E. Christensen, I.M.N. Vold, K.M. Vårum, Chain stiffness and extension of chitosans and periodate oxidised chitosans studied by size-exclusion chromatography combined with light scattering and viscosity detectors, Carbohydr. Polym. 74 (2008) 559-565, http://dx.doi.org/10.1016/j.carbpol.2008.04.012.

[26] J. Maia, M.P. Ribeiro, C. Ventura, R.A. Carvalho, I.J. Correia, M.H. Gil, Ocular injectable formulation assessment for oxidized dextran-based hydrogels, Acta Biomater. 5 (2009) 1948-1955, http://dx.doi.org/10.1016/j.actbio.2009.02.008.

[27] J. Maia, R.A. Carvalho, J.F.J. Coelho, P.N. Simões, M.H. Gil, Insight on the periodate oxidation of dextran and its structural vicissitudes, Polymer (Guildf). 52 (2011) 258-265, http://dx.doi.org/10.1016/j.polymer.2010.11.058.

[28] R. Clough, High-energy radiation and polymers: a review of commercial processes and emerging applications, Nucl. Instrum. Meth. Phys. Res. Sect. B Beam Interact. Mater. Atoms. 185 (2001) 8-33. 10.1016/S0168-583X(01)00966-1.

[29] D. Kanjickal, S. Lopina, M.M. Evancho-Chapman, S. Schmidt, D. Donovan, Effects of sterilization on poly(ethylene glycol) hydrogels, J. Biomed. Mater. Res. Part A. 87A (2008) 608-617, http://dx.doi.org/10.1002/jbm.a.31811.

[30] S. Al-Assaf, X. Coqueret, K. Zaman, H. Mohd, D. Murat, S.P. Ulanski, A. Albania, The Radiation Chemistry of Polysaccharides, International Atomic Energy Agency, Vienna, 2016 http://www-pub.iaea.org/MTCD/Publications/PDF/P1731_web.pdf (accessed December 27, 2017).

[31] M. Silindir, A.Y. Özer, Sterilization methods and the comparison of E-beam sterilization with gamma radiation sterilization, FABAD J. Pharm. Sci. 34 (2009) 43-53 (accessed March 26, 2018), https://pdfs.semanticscholar.org/f809/ 021b1e774f6749ae3cfb6ecc85e87d4dd3ef.pdf.

[32] M. Silindir, Y. Ozer, The effect of radiation on a variety of pharmaceuticals and materials containing polymers, PDA J. Pharm. Sci. Technol. 66 (2012) 184-199, http://dx.doi.org/10.5731/pdajpst.2012.00774.

[33] V.A. Sharpatyi, Radiation chemistry of polysaccharides: 1. Mechanisms of carbon monoxide and formic acid formation, High Energy Chem. 37 (2003) 369-372, http://dx.doi.org/10.1023/B:HIEC.0000003393.88711.e2.

[34] C. von Sonntag, Free-radical reactions of carbohydrates as studied by radiation techniques, Adv. Carbohydr. Chem. Biochem. (1980) 7-77, http://dx.doi.org/10 1016/S0065-2318(08)60019-0.

[35] M.R. Asam, G.L. Glish, Tandem mass spectrometry of alkali cationized polysaccharides in a quadrupole ion trap, J. Am. Soc. Mass Spectrom. 8 (1997) 987-995, http://dx.doi.org/10.1016/S1044-0305(97)00124-4.

[36] J. Simões, P. Domingues, A. Reis, F.M. Nunes, M.A. Coimbra, M.R.M. Domingues, Identification of anomeric configuration of underivatized reducing glucopyranosylglucose disaccharides by tandem mass spectrometry and multivariate analysis,
Anal. Chem. 79 (2007) 5896-5905, http://dx.doi.org/10.1021/ac070317i.

[37] C. Nunes, L. Silva, A.P. Fernandes, R.P.F. Guiné, M.R.M. Domingues, M.A. Coimbra, Occurrence of cellobiose residues directly linked to galacturonic acid in pectic polysaccharides, Carbohydr. Polym. 87 (2012) 620-626, http://dx.doi.org/10 1016/j.carbpol.2011.08.027.

[38] J. Tudella, F.M. Nunes, R. Paradela, D.V. Evtuguin, P. Domingues, F. Amado, M.A. Coimbra, A.I.R.N.A. Barros, M.R.M. Domingues, Oxidation of mannosyl oligosaccharides by hydroxyl radicals as assessed by electrospray mass spectrometry, Carbohydr. Res. 346 (2011) 2603-2611, http://dx.doi.org/10.1016/j.carres.2011. 09.011.

[39] A.S.P. Moreira, E.V. da Costa, D.V. Evtuguin, M.A. Coimbra, F.M. Nunes, M.R.M. Domingues, Neutral and acidic products derived from hydroxyl radicalinduced oxidation of arabinotriose assessed by electrospray ionisation mass spectrometry, J. Mass Spectrom. 49 (2014) 280-290, http://dx.doi.org/10.1002/jms. 3339.

[40] J. Simões, A.S.P. Moreira, E. da Costa, D. Evtyugin, P. Domingues, F.M. Nunes, M.A. Coimbra, M.R.M. Domingues, Oxidation of amylose and amylopectin by hydroxyl radicals assessed by electrospray ionisation mass spectrometry, Carbohydr. Polym. 148 (2016) 290-299, http://dx.doi.org/10.1016/j.carbpol.2016.03.034.

[41] ISO 11737-1, Sterilization of medical devices - Microbiological methods - Part 1: Determination of a population of microorganisms on products, 2006. https://www. iso.org/standard/38711.html (accessed March 26, 2018).

[42] ISO 11137-2, Sterilization of health care products - Radiation - Part 2: Establishing the sterilization dose, 2012. https://www.iso.org/standard/51238.html (accessed March 26, 2018).

[43] ISO 11737-2, Sterilization of medical devices - Microbiological methods - Part 2: Tests of sterility performed in the definition, validation and maintenance of a sterilization process, 2009. http://www.benebion.com/docs/cer/iso_11737-2_ 2009-en.pdf (accessed August 20, 2017)

[44] M.A. Coimbra, I. Delgadillo, K.W. Waldron, R.R. Selvendran, Isolation and Analysis of Cell Wall Polymers from Olive Pulp, in: Springer Berlin Heidelberg, 1996: pp. 19-44. 10.1007/978-3-642-60989-3_2.

[45] N. Blumenkrantz, G. Asboe-Hansen, New method for quantitative determination of uronic acids, Anal. Biochem. 54 (1973) 484-489, http://dx.doi.org/10.1016/00032697(73)90377-1

[46] I. Ciucanu, F. Kerek, A simple and rapid method for the permethylation of carbohydrates, Carbohydr. Res. 131 (1984) 209-217, http://dx.doi.org/10.1016/00086215(84)85242-8.

[47] E.L. Jackson, C.S. Hudson, The structure of the products of the periodic acid oxidation of starch and cellulose 1, J. Am. Chem. Soc. 60 (1938) 989-991, http://dx doi.org/10.1021/ja01272a001.

[48] I. Sulaeva, K.M. Klinger, H. Amer, U. Henniges, T. Rosenau, A. Potthast, Determination of molar mass distributions of highly oxidized dialdehyde cellulose by size exclusion chromatography and asymmetric flow field-flow fractionation, Cellulose 22 (2015) 3569-3581, http://dx.doi.org/10.1007/s10570-015-0769-x.

[49] K.A. Kristiansen, A. Potthast, B.E. Christensen, Periodate oxidation of polysaccharides for modification of chemical and physical properties, Carbohydr. Res. 345 (2010) 1264-1271, http://dx.doi.org/10.1016/j.carres.2010.02.011.

[50] H. Kamal, G.M. Sabry, S. Lotfy, N.M. Abdallah, P. Ulanski, J. Rosiak, E.A. Hegazy, Controlling of degradation effects in radiation processing of starch, J. Macromol. Sci. Part A 44 (2007) 865-875, http://dx.doi.org/10.1080/10601320701407961.

[51] H.-J. Chung, Q. Liu, Molecular structure and physicochemical properties of potato and bean starches as affected by gamma-irradiation, Int. J. Biol. Macromol. 47 (2010) 214-222, http://dx.doi.org/10.1016/j.ijbiomac.2010.04.019.

[52] S. Lotfy, Controlling degradation of low-molecular-weight natural polymer "dextrin" using gamma irradiation, Int. J. Biol. Macromol. 44 (2009) 57-63, http://dx. doi.org/10.1016/j.ijbiomac.2008.10.002.

[53] G.O. Phillips, G.J. Moody, G.L. Mattok, 710. Radiation chemistry of carbohydrates Part I. Action of ionising radiation on aqueous solutions of D-glucose, J. Chem. Soc (1958) 3522. 10.1039/jr9580003522.

[54] G.O. Phillips, G.J. Moody, 711. Radiation chemistry of carbohydrates. Part II. Irradiation of aqueous solutions of dextran with gamma radiation, J. Chem. Soc. (1958) 3534. http://10.1039/jr9580003534.

[55] A. Bisio, S. Guglieri, M. Frigerio, G. Torri, E. Vismara, U. Cornelli, D. Bensi, S. Gonella, L. De Ambrosi, Controlled $\gamma$-ray irradiation of heparin generates oligosaccharides enriched in highly sulfated sequences, Carbohydr. Polym. 55 (2004) 101-112, http://dx.doi.org/10.1016/j.carbpol.2003.08.017.

[56] J.-P. Jeun, Y.-K. Jeon, Y.-C. Nho, P.-H. Kang, Effects of gamma irradiation on the thermal and mechanical properties of chitosan/PVA nanofibrous mats, J. Ind. Eng. Chem. 15 (2009) 430-433, http://dx.doi.org/10.1016/j.jiec.2009.02.001.

[57] J.M. Wasikiewicz, F. Yoshii, N. Nagasawa, R.A. Wach, H. Mitomo, Degradation of chitosan and sodium alginate by gamma radiation, sonochemical and ultraviolet methods, Radiat. Phys. Chem. 73 (2005) 287-295, http://dx.doi.org/10.1016/j. radphyschem.2004.09.021.

[58] N. Nagasawa, H. Mitomo, F. Yoshii, T. Kume, Radiation-induced degradation of sodium alginate, Polym. Degrad. Stab. 69 (2000) 279-285, http://dx.doi.org/10. 1016/S0141-3910(00)00070-7.

[59] L. Relleve, N. Nagasawa, L.Q. Luan, T. Yagi, C. Aranilla, L. Abad, T. Kume, F. Yoshii, A. dela Rosa, Degradation of carrageenan by radiation, Polym. Degrad. Stab. 87 (2005) 403-410, http://dx.doi.org/10.1016/j.polymdegradstab.2004.09.003.

[60] A.-S.T. Ulset, H. Mori, M.Ø. Dalheim, M. Hara, B.E. Christensen, Influence of amino acids, buffers, and $\mathrm{pH}$ on the $\gamma$-irradiation-induced degradation of alginates, Biomacromolecules 15 (2014) 4590-4597, http://dx.doi.org/10.1021/ bm501386n.

[61] D.W. Lee, W.S. Choi, M.W. Byun, H.J. Park, Y.-M. Yu, C.M. Lee, Effect of $\gamma$-irradiation on degradation of alginate, J. Agric. Food Chem. 51 (2003) 4819-4823, 
http://dx.doi.org/10.1021/jf021053y.

[62] M. Sen, S. Rendevski, P.A. Kavaklı, A. Sepehrianazar, Effect of G/M ratio on the radiation-induced degradation of sodium alginate, Radiat. Phys. Chem. 79 (2010) 279-282, http://dx.doi.org/10.1016/j.radphyschem.2009.08.028.

[63] M. Şen, H. Atik, The antioxidant properties of oligo sodium alginates prepared by radiation-induced degradation in aqueous and hydrogen peroxide solutions, Radiat. Phys. Chem. 81 (2012) 816-822, http://dx.doi.org/10.1016/j.radphyschem.2012. 03.025.

[64] E. Bidzinska, K. Dyrek, T. Fortuna, M. Labanowska, S. Pietrzyk, EPR studies of thermally treated oxidized corn starch, Starch - Stärke. 56 (2004) 461-468, http:// dx.doi.org/10.1002/star.200400278.

[65] C. von Sonntag, H.-P. Schuchmann, The elucidation of peroxyl radical reactions in aqueous solution with the help of radiation-chemical methods, Angew. Chemie Int. Ed. English. 30 (1991) 1229-1253, http://dx.doi.org/10.1002/anie.199112291.

[66] A. Reis, P. Pinto, D.V. Evtuguin, C.P. Neto, P. Domingues, A.J. Ferrer-Correia, M.R.M. Domingues, Electrospray tandem mass spectrometry of underivatised acetylated xylo-oligosaccharides, Rapid Commun. Mass Spectrom. 19 (2005) 3589-3599, http://dx.doi.org/10.1002/rcm.2234.

[67] A.S.P. Moreira, M.A. Coimbra, F.M. Nunes, J. Simões, M.R.M. Domingues, Evaluation of the effect of roasting on the structure of coffee galactomannans using model oligosaccharides, J. Agric. Food Chem. 59 (2011) 10078-10087, http://dx. doi.org/10.1021/jf2021072.

[68] A.S.P. Moreira, M.A. Coimbra, F.M. Nunes, M.R.M. Domingues, Roasting-induced changes in arabinotriose, a model of coffee arabinogalactan side chains, Food Chem. 138 (2013) 2291-2299, http://dx.doi.org/10.1016/j.foodchem.2012.11. 130.

[69] L. Hough, T.J. Taylor, G.H.S. Thomas, B.M. Woods, 239. The oxidation of monosaccharides by periodate with reference to the formation of intermediary esters, J. Chem. Soc. (1958) 1212. 10.1039/jr9580001212.

[70] T.G. Halsall, E.L. Hirst, J.K.N. Jones, 269. Oxidation of carbohydrates by the periodate ion, J. Chem. Soc. (1947) 1427. 10.1039/jr9470001427. 